Article

\title{
Study on Heat Transfer Performance and Anti-Fouling Mechanism of Ternary Ni-W-P Coating
}

\author{
Lu Ren ${ }^{1}{ }^{1}$, Yanhai Cheng ${ }^{1, *}$, Jinyong Yang ${ }^{1}$ and Qingguo Wang ${ }^{2}$ \\ 1 School of Mechanical and Electrical Engineering, China University of Mining and Technology, \\ Xuzhou 221116, China; hypergalaxy@foxmail.com (L.R.); yangjinyong@cumt.edu.cn (J.Y.) \\ 2 Institute for Intelligent Systems, Faculty of Engineering and the Built Environment, University of \\ Johannesburg, Johannesburg 2006, South Africa; wangq@uj.ac.za \\ * Correspondence: chyh1007@cumt.edu.cn
}

Received: 6 March 2020; Accepted: 1 June 2020; Published: 4 June 2020

Featured Application: After a long period of use, the solar collector has to be cleaned due to the serious blocking and efficiency decline. In this work, we prepared ternary Ni-W-P coating to inhibit the fouling deposition. Also, the thermal conductivity of ternary Ni-W-P coating and heat transfer coefficient of composite material were analyzed to make identification of the heat transfer performance of a matrix with and without the ternary Ni-W-P coating after flow fouling experiment. This work can provide a reference for using anti-fouling coating to prolong the life cycle and cleaning period of equipment.

Abstract: Since the formation of fouling reduces heat transfer efficiency and causes energy loss, anti-fouling is desirable and may be achieved by coating. In this work, a nickel-tungsten-phosphorus (Ni-W-P) coating was prepared on the mild steel (1015) substrate using electroless plating by varying sodium tungstate concentration to improve its anti-fouling property. Surface morphology, microstructure, fouling behavior, and heat transfer performance of coatings were further reported. Also, the reaction path, transition state, and energy gradient change of calcite, aragonite, and vaterite were also calculated. During the deposition process, as the $\mathrm{W}$ and $\mathrm{P}$ elements were solids dissolved in the Ni crystal cell, the content of Ni element was obviously higher than that of the other two elements. Globular morphology was evenly covered on the surface. Consequently, the thermal conductivity of ternary Ni-W-P coating decreases from $8.48 \mathrm{~W} / \mathrm{m} \cdot \mathrm{K}$ to $8.19 \mathrm{~W} / \mathrm{m} \cdot \mathrm{K}$ with the increase of $\mathrm{W}$ content. Additionally, it goes up to $8.93 \mathrm{~W} / \mathrm{m} \cdot \mathrm{K}$ with the increase of heat source temperature $343 \mathrm{~K}$. Oxidation products are always accompanied by deposits of calcite-phase $\mathrm{CaCO}_{3}$ fouling. Due to the low surface energy of Ni-W-P coating, $\mathrm{Ca}^{2+}$ and $\left[\mathrm{CO}_{3}\right]^{2-}$ are prone to cross the transition state with a low energy barrier of $0.10 \mathrm{eV}$, resulting in the more formation of aragonite-phase $\mathrm{CaCO}_{3}$ fouling on ternary Ni-W-P coating. Nevertheless, because of the interaction of high surface energy and oxidation products on the bare matrix or Ni-W-P coating with superior $\mathrm{W}$ content, free $\mathrm{Ca}^{2+}$ and $\left[\mathrm{CO}_{3}\right]^{2-}$ can be easy to nucleate into calcite. As time goes on, the heat transfer efficiency of material with Ni-W-P coating is superior to the bare surface.

Keywords: anti-fouling performance; first principle; heat-transfer characteristic; surface modification; thermal conductivity; transient state

\section{Introduction}

The fouling problem, which is regarded as "the main unresolved problem in heat transfer", is mainly generated by the deposition of particulates, impurities, salts, and various organic species onto heat transfer surfaces [1-3]. It can be seen from Figure 1 that the fouling of calcium carbonate 
and magnesium carbonate accumulate on the tube surface of solar-energy and water-inlet of solar collectors. Due to the corrosion caused by long-term use of water delivery pipes and valves, iron oxides and copper oxides accumulate on the outlet of insulating water tank. Furthermore, the influence of corrosion products on the heat exchanger surface results in further corrosion of metal. After long periods of use in the circumstance of hard water, the solar collector has to be cleaned due to the serious blocking and the reduced efficiency. Fouling inevitably increases the fouling resistance and reduces the heat transfer effectiveness, thus bringing about higher fuel consumption, maintenance costs.

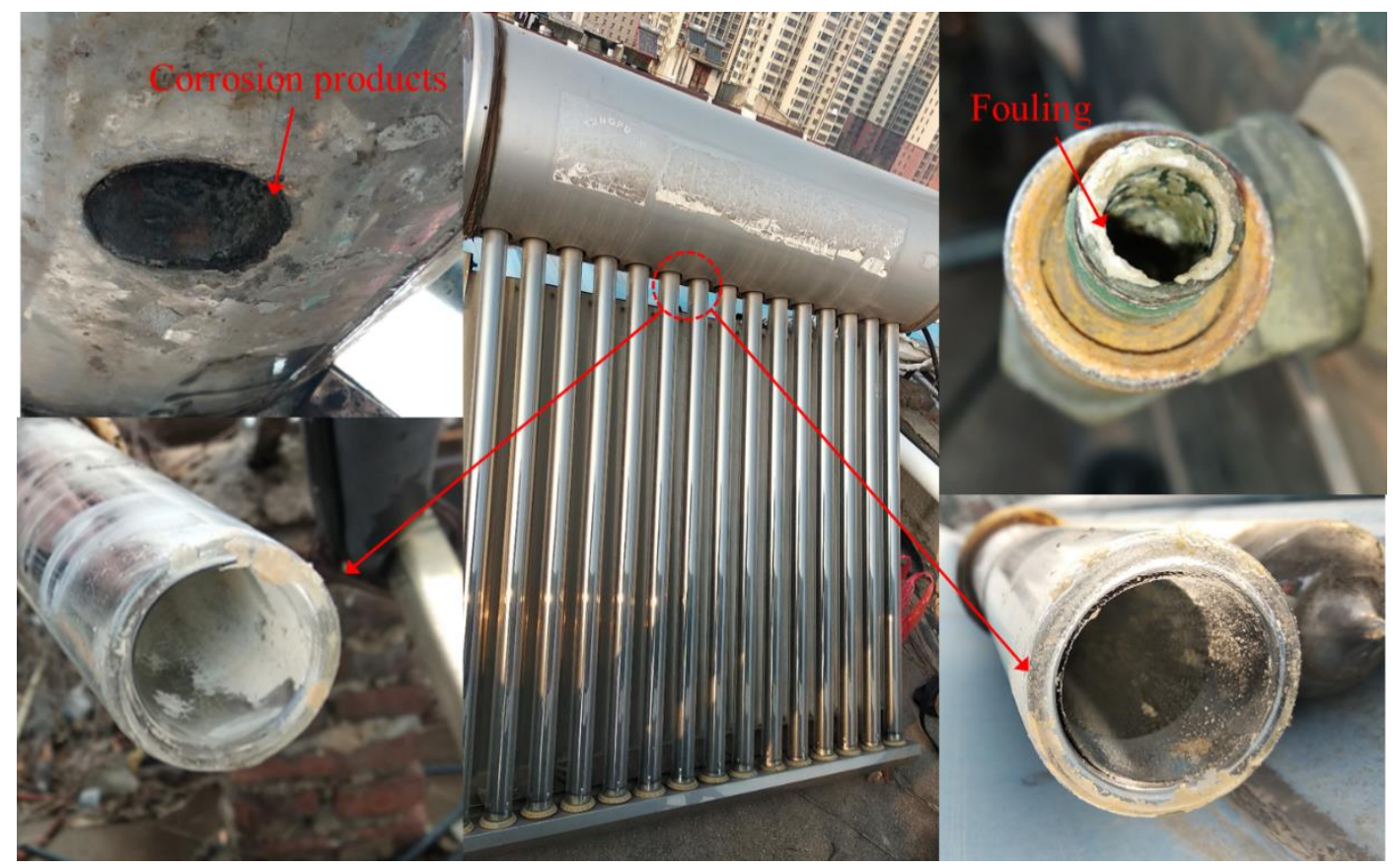

Figure 1. Fouling on the pipes of solar collectors after long periods of use.

Since the 1980s, electroless plating has been treated as an operational technology of the surface modification, attracting widespread attention [4-8]. The results prove that electroless Ni-P-based coating is an advantageous method for fouling inhibition [9-13]. The mass gain method [10,11,14], the calcium ion loss method [12], and the fouling resistance method [15] were commonly used for measuring the deposition process of calcium carbonate fouling on materials surface. The surface is easy to be corroded and the oxidized surface is prone to form a "transition interface", which works as a "bridge" to connect the matrix and fouling. The "transition interface" consists of corrosion or oxidation, and the lattice of the "transition interface" layer can be easily matched with the lattice of fouling. Therefore, the adhesion of fouling on the corrosion interface seems to be easier $[13,16,17]$. Simultaneously, compared with uncoated pipe, the tube with electroless coating can significantly improve the property of condensation heat transfer, showing the coexistence of dropwise and filmwise on most working conditions $[18,19]$. Calcium carbonate is the principal component of fouling in industry. It is easy to adhere to the surface of the heat transfer wall to form fouling, affecting the heat transfer efficiency. The compactness and adhesion strength of fouling on the surface of heat exchange wall depends on its crystal structure [20]. Meanwhile, the evidence demonstrates that the induction period of fouling can be effectively prolonged by the surface free energy of coating. Solubility of calcium carbonate reduces with the up of solution temperature, and the studies prove that the dissolved metal cation can further accelerate the deposition process of fouling [2,21,22]. From the preceding decades, the nucleation of $\mathrm{CaCO}_{3}$ molecules have been studied theoretically based on molecular dynamics (MD) and density functional theory (DFT). Based on MD, the grain boundary energy was computed to investigate the change of energy in the aggregation process of $\mathrm{Ca}^{2+}$ and $\left[\mathrm{CO}_{3}\right]^{2-}$. When the distance of interfaces between $\mathrm{CaCO}_{3}$ particles came close to colliding, the dielectric constant of 
water became small [23]. Jun, Kawano simulated calcium carbonate at high pressure and the phase transition between calcite and aragonite, and results show that in the 300-800 K temperature range, calcite transforms to aragonite at a pressure of around $8 \mathrm{GPa}$ [24]. Additionally, when heated under high pressure, the first-order unsymmetric phase transition of calcite phase occurs first, and then the second-order transition of calcite and aragonite phases happens at a higher temperature [25]. Kazunori Kadota proved that the aggregation of primary particles leaded to the formation of calcite clusters. Because positive and negative charges attract each other, many particles form clusters in the same direction [26]. Due to the ions, $\mathrm{Ca}^{2+}$ and $\left[\mathrm{CO}_{3}\right]^{2-}$ seem to be easily combined. In a real environment, dissolved metal cations in $\mathrm{CaCO}_{3}$ solution also affect the growth of $\mathrm{CaCO}_{3}$, resulting in irregular nucleation during its crystal formation and inadequacy connecting of valence bonds. Thereupon, because of the unsaturation of valence bond, its electrostatic attraction, active centers and surface energy are all large, thus, it has a greater attraction to the surrounding ions. However, the nucleation energy of calcite, aragonite, and vaterite, which is a critical problem of industrial efficiency, remains elusive and is a field of intense research.

Based on this, we specially built a fouling environment. $\mathrm{Ca}^{2+}$, as well as $\left[\mathrm{CO}_{3}\right]^{2-}$, were induced to deposit on the surface of substrate and coating. The object of this project is to study the forming mechanism of calcium carbonate fouling and heat transfer performance on Ni-W-P electroless coating. Comparison between the heat transfer performance of a substrate with and without the Ni-W-P coating after fouling experiment was also investigated. Moreover, we give a theoretical simulation on the reaction path, transition state, and energy gradient change of calcite, aragonite, and vaterite to figure out that why calcite, aragonite, and vaterite deposit on the different surfaces.

\section{Experimental Section}

\subsection{Materials and Preparation}

Under the condition of stable heat transfer, the thermal conductivity of the material is measured with the plate method in the thermal conductivity meter. Thus, the sample must be the cylindrical form. At the same time, as the cylinder sample has a constant radial size, the relative error is small compared with the square sample in the fouling solution. So, the cylinder samples were used in this work. Firstly, we produced the substrate specimens with mild steel (Table 1) (diameter is equal to $30 \mathrm{~mm}$, thickness is equal to $5 \mathrm{~mm}$ ) by wire cutting, and then polished them with $320 \#, 600 \#, 800 \#, 1200 \#$ metallographic sandpaper, respectively. After that, the polished specimens, which are firstly stored in alcohol solution, were then ultrasonic cleaned. It is noted that the specimens should be degreased at $348 \mathrm{~K}$ (Table 2). The use of degreasing agent is utilized to remove grease on the specimen surface with the method of saponification and emulsification reaction. Polyxyethylene octylphosphonol ether is an anionic surfactant whose charged group is prone to be adsorbed on the surface of metal and solid dust. Thus, impurity and polyxyethylene octylphosphonol ether have the same charge and repels each, leading to the decrease of adhesion. At a higher temperature (above $343 \mathrm{~K}$ ), polyxyethylene octylphosphonol ether has the excellent effect of degreasing and dewaxing. Before electroless plating preparation, electroless Ni-W-P baths must be adjusted by sodium hydroxide at $\mathrm{pH} 7.8 \pm 0.2$. During the operation of $\mathrm{pH}$ adjusting, the bath should be vigorously stirred. When the specimens were put into the bath for preparation, the bath should be kept static and its temperature was maintained at $358 \mathrm{~K}$ (Table 3). The plating time goes $2 \mathrm{~h}$ in thermostat water bath. When finishing preparation, the specimens were ultrasonic cleaned again.

Table 1. Chemical composition of mild steel.

\begin{tabular}{ccccccccc}
\hline \multirow{2}{*}{ Name } & \multicolumn{8}{c}{ Composition (Mass\%) } \\
\cline { 2 - 9 } & $\mathbf{C}$ & Mn & Si & S & P & Cr & Ni & Fe \\
\hline Mild Steel & 0.16 & 0.6 & 0.3 & 0.05 & 0.05 & 0.031 & 0.012 & Bal \\
\hline
\end{tabular}


Table 2. Formulation of alkali washing and degreasing.

\begin{tabular}{ccccc}
\hline Reagent & $\mathrm{NaOH}$ & $\mathrm{Na}_{2} \mathrm{CO}_{3}$ & $\mathrm{Na}_{3} \mathbf{P O}_{4}$ & Polyoxyethylene Octylphenol Ether \\
\hline Concentration $(\mathrm{g} / \mathrm{L})$ & $20 \sim 30$ & $20 \sim 25$ & $35 \sim 40$ & $4 \sim 6$ \\
\hline
\end{tabular}

Table 3. Main components of electroless Ni-W-P plating solution.

\begin{tabular}{ccccccc}
\hline $\begin{array}{c}\text { Specimen } \\
\text { Number }\end{array}$ & $\begin{array}{c}\text { Nickel } \\
\text { Sulfate (g/L) }\end{array}$ & $\begin{array}{c}\text { Ammonium } \\
\text { Acetate }(\mathrm{g} / \mathrm{L})\end{array}$ & $\begin{array}{c}\text { Sodium } \\
\text { Citrate }(\mathrm{g} / \mathrm{L})\end{array}$ & $\begin{array}{c}\text { Lactic Acid } \\
(\mathrm{g} / \mathrm{L})\end{array}$ & $\begin{array}{c}\text { Sodium } \\
\text { Hypophosphite }(\mathrm{g} / \mathrm{L})\end{array}$ & $\begin{array}{c}\text { Sodium } \\
\text { Tungstate }(\mathrm{g} / \mathrm{L})\end{array}$ \\
\hline 1 & 18 & 12 & 35 & 20 & 20 & 25 \\
2 & 18 & 12 & 35 & 20 & 20 & 30 \\
3 & 18 & 12 & 35 & 20 & 20 & 40 \\
4 & 18 & 12 & 35 & 20 & 20 & 45 \\
5 & 18 & 12 & 35 & 20 & & \\
\hline
\end{tabular}

\subsection{Fouling Experiments and Heat Transfer Performance}

Figure 2 displays the schematic of the flowing fouling experimental rig. The experimental system is primarily composed of a water heating system (red line), a fouling solution system, and a data acquisition system. First of all, the water in the water tank was heated to $343 \mathrm{~K}$ by the heating rod, and then was pumped in the inner tube of the heat exchanger through the transmission of the water pump. The flow and temperature of the hot water were adjusted by the two-way regulating valve and the water tank power controller, respectively. When the inlet and outlet water temperatures in the heat exchanger were kept constant, $0.1 \mathrm{~g} / \mathrm{L} \mathrm{CaCl}_{2}$ solution and $0.1 \mathrm{~g} / \mathrm{L} \mathrm{NaHCO} 3$ solution in pear-shaped separating funnel were mixed to $0.1 \mathrm{~g} / \mathrm{L}$ supersaturated solution through magnetic stirring apparatuses. With the increase of temperature and the change of flow rate, the crystals of calcium carbon in the supersaturated solution precipitate, resulting in the fouling deposition. The use of $\mathrm{CaCl}_{2}$ and $\mathrm{NaHCO}_{3}$ can be hydrolyzed into $\mathrm{Ca}^{2+}, \mathrm{Cl}^{-}, \mathrm{Na}^{+}$, and $\mathrm{HCO}_{3}{ }^{-}$in fouling solution [27], and then further electrolysis can occur. The dynamic reaction is as follows,

$$
\begin{gathered}
\mathrm{HCO}_{3}^{-} \rightleftharpoons \mathrm{H}^{+}+\mathrm{CO}_{3}^{2-} \\
\mathrm{HCO}_{3}^{-}+\mathrm{H}^{+} \rightleftharpoons \mathrm{H}_{2} \mathrm{CO}_{3} \\
\mathrm{H}_{2} \mathrm{CO}_{3} \rightleftharpoons \mathrm{CO}_{2}+\mathrm{H}_{2} \mathrm{O} \\
\mathrm{H}_{2} \mathrm{O} \rightleftharpoons \mathrm{OH}^{-}+\mathrm{H}^{+} \\
\mathrm{Ca}^{2+}+\mathrm{CO}_{3}^{2-} \rightleftharpoons \mathrm{CaCO}_{3}
\end{gathered}
$$

Then, the mixed $0.1 \mathrm{~g} / \mathrm{L}$ supersaturated solution of fouling is transported to the shell side of the heat exchanger with the function of peristaltic pump (Table 4).

Table 4. Experimental parameters of flow fouling.

\begin{tabular}{cccccc}
\hline Item & $\begin{array}{c}\text { Water } \\
\text { Temperature } / \mathbf{K}\end{array}$ & $\begin{array}{c}\text { Water and Solution } \\
\text { Velocity/m. } \mathbf{s}^{\mathbf{- 1}}\end{array}$ & $\begin{array}{c}\text { Concentration of } \\
\mathrm{CaCO}_{3} \text { Solution } / \mathbf{g} \cdot \mathbf{L}^{-\mathbf{1}}\end{array}$ & $\begin{array}{c}\text { Recording } \\
\text { Interval/s }\end{array}$ & $\begin{array}{c}\text { Experimental } \\
\text { Time } / \mathbf{h}\end{array}$ \\
\hline Parameter & 343 & 0.15 & 1.0 & 120 & 72 \\
\hline
\end{tabular}

In Figure 3, the experimental heat exchange device is similar to a double-pipe (heat) exchanger. The inner tube of the heat exchanger is connected with the heating circulating water of $343 \mathrm{~K}$, which is to keep the temperature constant in fouling solution system. Meanwhile, the outer tube is filled with the fouling solution and heated by the water temperature of the inner tube. Before the experiment, the specimens of the fouling test are embedded into the foam board and placed in the detachable lids of the measurable anti-fouling heat exchanger. So, the working surfaces of the specimens are parallel to the pipe centerline, which can reduce the effect of obstruction of the specimen surfaces on the water 
flow in the pipe and ensure that the specimens do not have galvanic effect with other metal surfaces. At the same time, the screw in the inner tube was used to fix the chip thermocouple in the nearby area of each specimen and the temperature of the fouling solution can be measured continually.

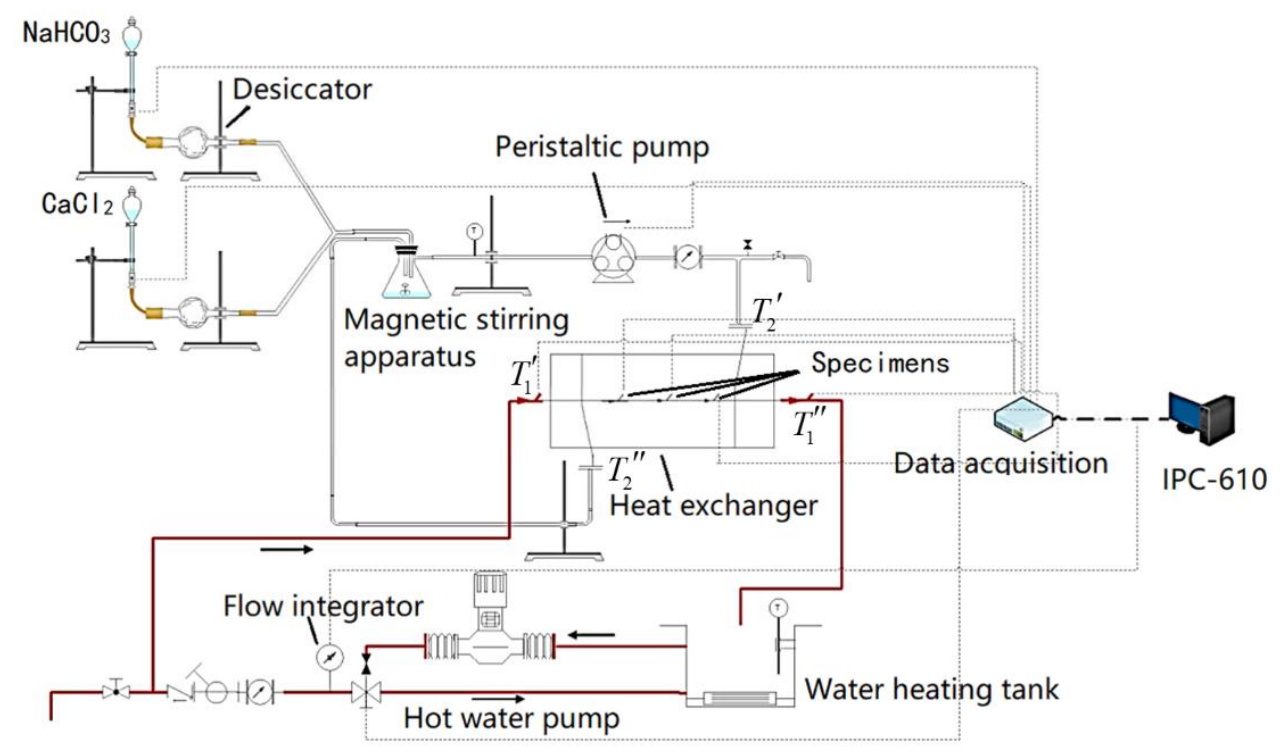

Figure 2. Schematic diagram of flow fouling experimental rig.

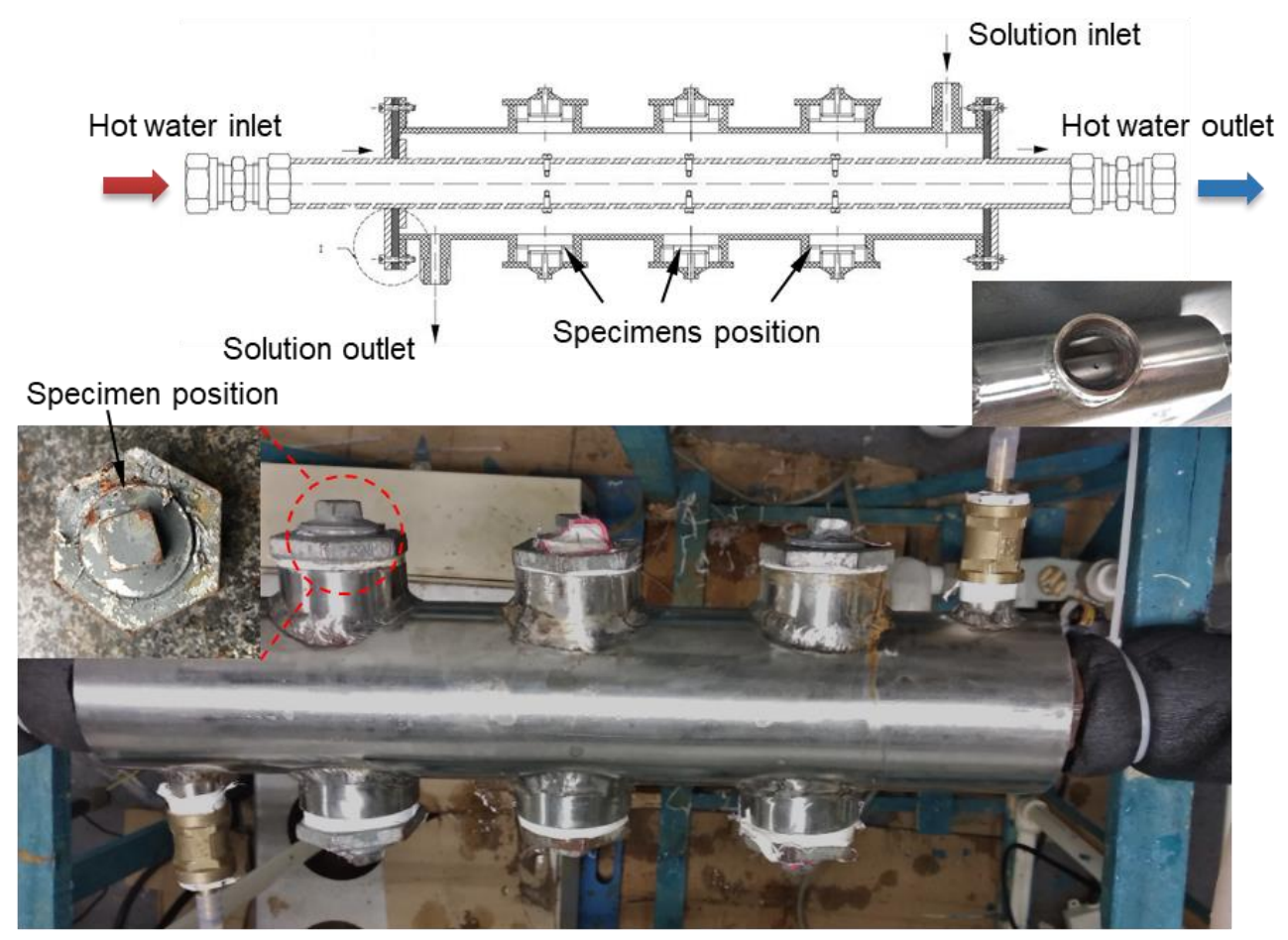

Figure 3. Measurable anti-fouling heat exchanger.

To avoid the fouling solution deposited on the inner surfaces of pipeline, reduce errors in the experiment, maintain the heat transfer effect of the inner tube, this heat exchanger is made of stainless steel in this experiment [28].

It should be noted that the trend of fouling deposition, which is on the heat exchanger surfaces formed of different materials, was recorded. When the experiment is done, mass gain method was 
adopted to measure the rate of fouling. Besides, the surface morphology of specimens and crystal form were observed. The fouling deposition rate $S$ is defined as

$$
\mathrm{S}=\left(m_{1}-m_{0}\right) / \mathrm{a}
$$

where $m_{0}$ and $m_{1}$ are the mass of the specimen before and after flow fouling experiment, g. $a$ is the surface area, $\mathrm{m}^{2}$.

After being weighed, the thermal resistance and thermal conductivity of specimens were tested by thermal conductivity meter (DRL-III, Xiangtan instrument Co Ltd., Xiangtan, China) and the changes of coated surface with fouling layer and the bare surface with fouling layer were further analyzed $[29,30]$. Firstly, the thermal conductivity of bare substrate was tested and the equation was given by Goldstein, R.J. [31].

$$
\lambda_{1}=\Phi_{1} \delta_{1} /\left[A\left(T_{1}-T_{2}\right)\right]
$$

where $\Phi_{1}$ is the heat exchange amount of substrate, W. $\delta_{1}$ is the thickness of substrate, $\mathrm{m} . A$ is the area of heat transfer, $\mathrm{m}^{2} . T_{1}$ and $T_{2}$ are the hot side and cool side temperature of substrate, respectively, $\mathrm{K}$.

The thermal conductivity $\lambda_{1}$ of the substrate is measured under the set temperature. As the thickness of ternary Ni-W-P coating is thinner than that of fouling layer and substrate. The steady state method is employed to calculate thermal conductivity of coating. The characterization of thermal physical parameters of micro-scale Ni-W-P coating will be further carried out in our subsequent research. Now, take the thermal conductivity of Ni-W-P coating into the equation

$$
\Phi_{2}=A\left(T_{1}-T_{3}\right) /\left(\delta_{1} / \lambda_{1}+\delta_{2} / \lambda_{2}\right)
$$

where $\Phi_{2}$ is the heat exchange amount of substrate with Ni-W-P coating, W. $\delta_{2}$ is the thickness of $\mathrm{Ni}-\mathrm{W}-\mathrm{P}$ coating, $\mathrm{m} . \lambda_{2}$ is the thermal conductivity of Ni-W-P coating, $\mathrm{W} /(\mathrm{m} \cdot \mathrm{K}) . T_{3}$ is the cool side temperature of Ni-W-P coating, $\mathrm{K}$.

We can obtain the thermal conductivity of Ni-W-P coating from Equation (8). Then, the change of it with the variety of ambient temperature, as well as differences of $\mathrm{W}$ element content at constant temperature can be analyzed. Put $\lambda_{1}$ and $\lambda_{2}$ into the equation

$$
\Phi_{3}=A\left(T_{1}-T_{4}\right) /\left(\delta_{1} / \lambda_{1}+\delta_{2} / \lambda_{2}+\delta_{3} / \lambda_{3}\right)
$$

where $\Phi_{3}$ is the heat exchange amount of substrate with Ni-W-P coating after flow fouling experiment, $\mathrm{W}$. $\delta_{3}$ is the thickness of fouling layer, $\mathrm{m} . \lambda_{3}$ is the thermal conductivity of fouling layer, $\mathrm{W} /(\mathrm{m} \cdot \mathrm{K}) \cdot T_{4}$ is the cool side temperature of fouling layer, $\mathrm{K}$. Thus, the fouling resistance can be calculated by

$$
R=A \Delta t / \Phi
$$

Substantially, the change process of fouling resistance $\mathrm{R}$ is further calculated with Equation (10). Compare the changes of fouling resistance of the specimen with or without Ni-W-P coating after fouling, the heat transfer coefficient K [32] can be obtained from

$$
K=d / R
$$

After that, crystal shape and thermal resistance of fouling layer were analyzed.

\subsection{Surface Morphology, Microstructure, and Phase Composition}

After the specimens were fouled for a set time, specimens with fouling were taken out. After the process of fouling adhesion, surface morphology of fouled sample and Ni-W-P coating were characterized by means of a scanning electron microscopy (SEM, Model QuantaTM250, FEI, USA). Elementary changes of Ni-W-P coating were analyzed with energy dispersive spectroscopy (EDS, 
Model QuantaTM250, FEI, USA). Crystal forms of fouling on the surface of Ni-W-P coating and bare mild steel were studied with the method of X-ray diffraction (XRD, D8 ADVANCE, Bruke, Germany). Through the results of scanning electron microscopy and $X$-ray diffraction on different surfaces, different phase calcium carbonate can be determined.

\subsection{First Principle on Transformation of Calcite, Aragonite, and Vaterite}

Calcium carbonate is a salt that heat transmits via the vibration of atoms. Atoms in calcium carbonate crystals are bound together by interatomic forces. The interaction force between atoms can be obtained by derivation of atomic potential energy [33].

$$
F=-d \phi / d x
$$

where $d x$ is the interatomic distance, $\AA$.

While the distance between atoms is far, the nucleus of one atom is attracted by the electrons of the other atom. Whereas, when the atoms are close to each other, the electron orbits of different atoms will overlap. Atoms will always vibrate near their equilibrium positions. The motion of each atom is limited by the potential energy of its neighbors, while the differences of binding energy of the calcite, aragonite, and vaterite crystals in calcium carbonate fouling deposited on the heat transfer surface was seldom reported. Therefore, the interaction force between atoms and the density of states of them were studied respectively in this work.

Material Studio 8.0 software was utilized for the simulation. Firstly, three models of calcite, aragonite, and vaterite were established and the numbers of atoms per cell were all 120 . The primary growth surface $\left(\begin{array}{l}0 \\ 0\end{array}\right.$ 1) was utilized to build super-cell [34]. The geometry optimization in Dmol ${ }^{3}$ module serves to minimize the energy of super-cell. Also, electronic exchange was disposed with the Perdew-Burke-Ernzerhof (PBE) [35,36] functions of Generalized Gradient Approximation (GGA) when minimizing the energy between electrons. In the brillouin area, the k-space grid points are chosen with Monkhorst-Pack [37]. This is because the lower the coverage of the surface is, the stronger the interaction between the adsorbed material and the substrate surface is [38]. Linear synchronous transit (LST) and quadratic synchronous transit method (QST) in TS search module is utilized to calculate the intermediate state. Firstly, initial states (calcite, aragonite, vaterite) were established and the geometry optimization in $\mathrm{Dmol}^{3}$ serves the relaxed geometry of them. Then LST/QST method in TS search was used to get the vibrational modes of the TS. Specifically, initial structure started from the low-energy reactants and guided by the tangent of the ST path at the current position. Then the structure marched along the response path (climbing step) hypothesized by LST/QST. The purpose is to make the structure of reactants reach the highest energy point of the hypothetical path (near the secondary region of the real transition state). When a certain criterion is satisfied, the exact transition state was calculated subsequently. When the transition state has only one imaginary frequency, the calculation of the corresponding transition state is completed as it has only one imaginary frequency [39]. Also, its vibration mode should be used to check whether the direction of vibration connects the reactant with the terminal state.

After that, the frequency analysis and calculation of intermediate and transition states are carried out at the same level to verify the correctness and interconnection of them. Furthermore, the reaction path, transition state, and energy gradient change rule of calcite, aragonite, and vaterite are further studied. Transition state structures of calcium carbonate and their analysis will be researched in later articles.

\section{Results}

\subsection{Surface Morphology and Microstructure}

As shown in Figure 4a,b, fouling were deposited on the surfaces of the specimens. Compared with the fouling on the surface of the coated specimen, red products on the uncoated specimen were caused 
by the corrosion products generated on the bare substrate surface after the flow fouling experiment. Therefore, there are not only calcium carbonate fouling but also iron rust formed on the substrate surface. The result conforms to our previous studies $[10,13]$ and proves that Ni-W-P has an admirable effect on anti-fouling performance. After calculating the mass change of the fouled specimens, it was found that there is no obvious rule between the mass change and the $\mathrm{W}$ content in the coating, while the certainty is that the mass gain of fouling on all the coated specimen is less than that of the bare substrate surface in the same period. Due to the difference of fouling adhesion, the deposit growth rate is the most significant parameter during the process [40], the thickness of fouling layer changes. As a result, the thermal resistance of the fouling layer also increases notably. In other words, the heat transfer coefficient of the untreated material has been affected partly due to the existence of Ni-W-P coating. As shown in Figure 4, the result reveals that the fouling on the surface of the specimen did not change significantly with the increase of $\mathrm{W}$ content. Because of the scouring effect of water flow and the influence of Van der Waals force in the molecules, the deposited fouling could fall off on the surface of the specimens and the mass change shows irregularly. Thus, the phenomenon of mass gain of fouling is inconsistent with our previous study in static fouled solution $[10,16]$. Whereas, it is certain that the existence of Ni-W-P coating, the surface tension decreases, which makes it more difficult for fouling to adhere and the deposition of fouling has been inhibited.

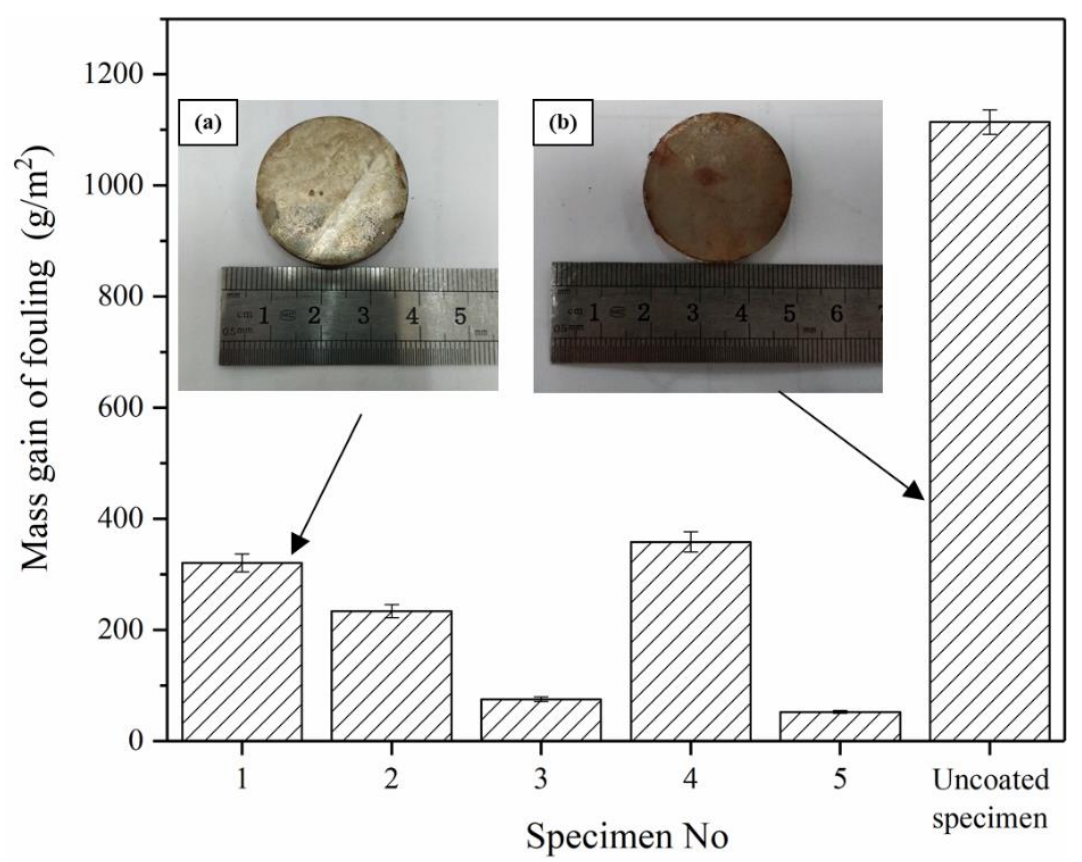

Figure 4. Mass change of coated specimens after $72 \mathrm{~h}$ fouling (a) macro appearance of specimen with Ni-W-P coating after flow fouling; (b) macro appearance of bare specimen after flow fouling.

To study the thickness and structure of the fouling deposited on the coated surface, scanning electron microscopy with energy dispersive spectroscopy was employed to test the structure of the deposited Ni-W-P coating. In Figure 5a, we can obviously observe that the surface of Ni-W-P coating is well-organized with cell body lines. The appearance of the globular morphology, which is in the form of the salient of the cell body, can be explained as the uneven deposition of $P$ element. Without $P$ element, Ni would grow orderly in accordance with the structure of face-centered cubic. The P element can densify the cell body of the coating and co-deposit the $\mathrm{Ni}$ on the substrate surface. During this process, $\mathrm{P}$ atoms will hold the positions of several $\mathrm{Ni}$ atoms, thus forming Ni-P supersaturated solid solution. When it increases to a certain stage, the Ni-W-P coating cannot array orderly in accordance with the structure of crystal Ni. Consequently, the Ni-W-P coating shows an amorphous structure, which can be proved by the XRD result. 

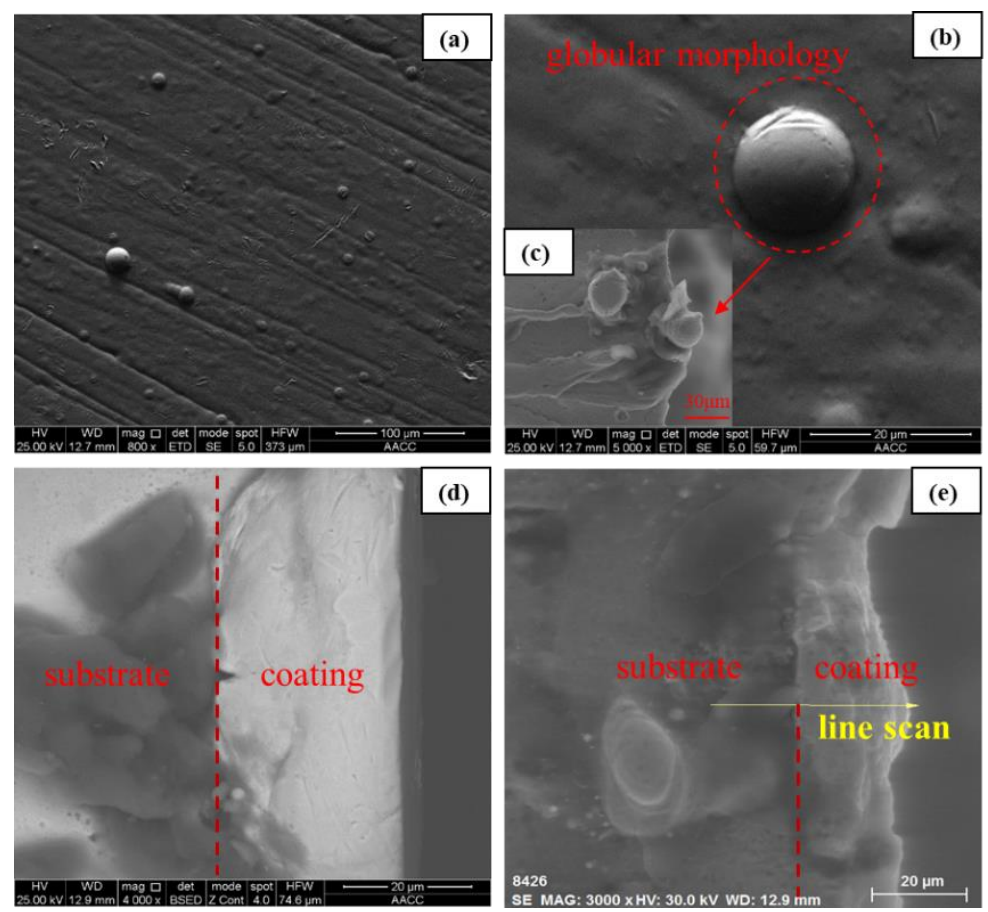

Figure 5. (a) Surface morphology of specimen 1 after electroless plating; (b) Surface morphology of nickel accumulation; (c) Cross-sectional morphology of nickel accumulation; (d) Back scattered-electron cross-sectional image of Ni-W-P coating of specimen 1; (e) Scattered-electron cross-sectional image of Ni-W-P coating of specimen 1 .

As can be seen in Figure $5 b, c$, the color of the tissue changes distinctly. It turns out that the globular morphology is filled with $\mathrm{Ni}[\mathrm{W}, \mathrm{P}]$ structure. The thickness of globular morphology is larger than that of the coating in Figure 5c. The possible explanation for this is the local inhomogeneity of the bare substrate surface that leads the excessive deposition of $\mathrm{Ni}[\mathrm{W}, \mathrm{P}]$ in the hole. Meanwhile, we cut the cross sections of several areas in order to calculate the heat transfer behavior of Ni-W-P coating. It was found that the thickness distribution of Ni-W-P coating after $2 \mathrm{~h}$ plating is $20 \mu \mathrm{m} \pm 2 \mu \mathrm{m}$. According to the Figure 6, there are apparent peaks of $\mathrm{Ni}, \mathrm{W}$, and $\mathrm{P}$ at the cross section. As the $\mathrm{W}$ and $\mathrm{P}$ elements were solid dissolved in the $\mathrm{Ni}$ crystal cell, the content of Ni element is obviously higher than that of the other two elements. Here, we calculate the heat transfer of the Ni-W-P coating uniformly without local distinction.

As shown in Figure 7, SEM tests were performed on specimens after $72 \mathrm{~h}$ of fouling. Figure $7 \mathrm{a}, \mathrm{b}$ exhibit the surface morphology of the uncoated mild steel. It is notable that there are a large number of fouling deposits on the surface in the form of massive and columnar particles, as well as agglomerates. Columnar fouling is also surrounded by loose-cotton-flocculent fouling. Based on the previous results, uncoated mild steel is primary composed of massive calcite and columnar aragonite, while calcite-phase $\mathrm{CaCO}_{3}$ fouling takes up a high proportion. A considerable amount of fouling indicates that the induction stage of the fouling deposition process on the bare substrate was ended and the heat transfer of the specimen surface could be severely affected by the rapid growth of calcite-phase and aragonite-phase fouling. The deposited products on the surface of Figure $7 \mathrm{c}$ are principal acicular aragonite mixed with a small amount of massive calcite and oxide [41,42]. The grain sizes of aragonite were estimated to be significantly smaller than calcite grains [43]. In the vicinity of calcite-phase $\mathrm{CaCO}_{3}$ fouling (Figure 7e), oxidation products also deposit nearby. However, no oxidation products were found near the aragonite-phase $\mathrm{CaCO}_{3}$ fouling (Figure 7d). At the same time, we also carried out a typical observation at the edge of the specimens. It can be found that the edge of the specimen is covered by the calcite and oxide. No aragonite deposited on their margins. On the one hand, the fouling solution will periodically form the double-line vortices arranged regularly in opposite rotation 
direction when passing through the edge of the specimens. The formation of Kármán vortex street after the non-linear effect, leading to the increase of the pressure of fouling deposition on the edge of the specimen, as well as the difference of nucleation energy of the fouling lattice [44]. On the other hand, when the vortex appears, the fluid will produce a periodic alternating transverse force on the edge of specimens. The natural frequencies of similar phase of $\mathrm{CaCO}_{3}$ fouling nuclei keep close to each other, leading to resonance of the crystal nucleus and then the selective deposition of the corresponding phase fouling, as well as the nucleus growth. Further study on nucleation energy barriers and bonding changes of different crystal-phase $\mathrm{CaCO}_{3}$ fouling will be reported in Section 3.3 See Figure 8, the XRD patterns of fouling of coating and bare substrate show different. There is an amorphous peak due to the penetration of X-ray in thin fouling layer, which is according with the results of Figure 8. It also can be noticed that there are both diffraction peaks of calcium carbonate and amorphous peaks of $\mathrm{Ni}-\mathrm{W}-\mathrm{P}$ coating showing on the coated sample. However, as the fouling layer on the surface of the bare substrate is relatively thick, the X-ray is reflected when it reaches the surface of the fouling layer. Compared with the sole crystal form of $\mathrm{CaCO}_{3}$ on the bare surface, it indicates that more aragonite deposit on the surface of ternary Ni-W-P coating.
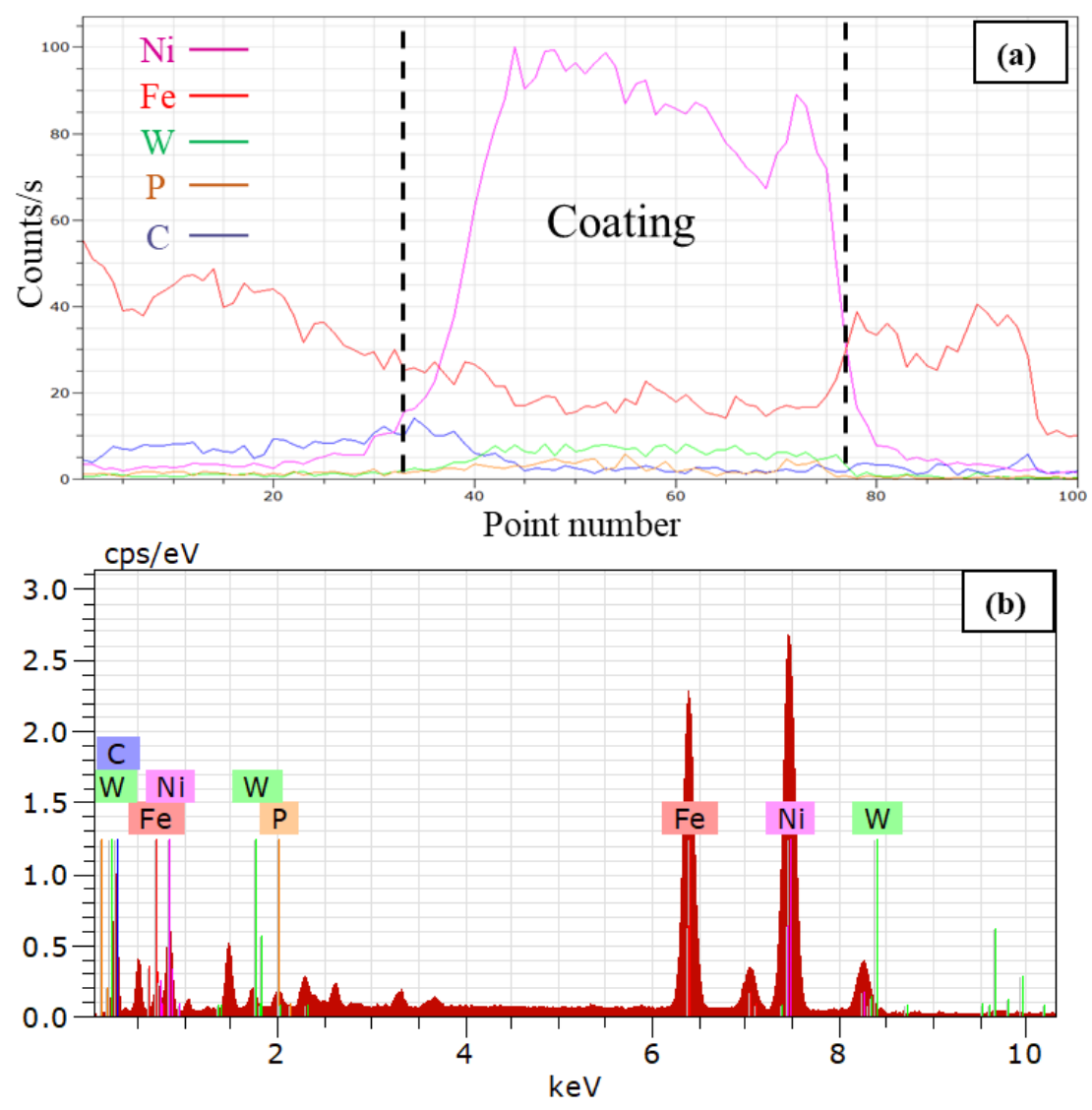

Figure 6. (a,b) Energy dispersive spectroscopy results of Figure 5e. 

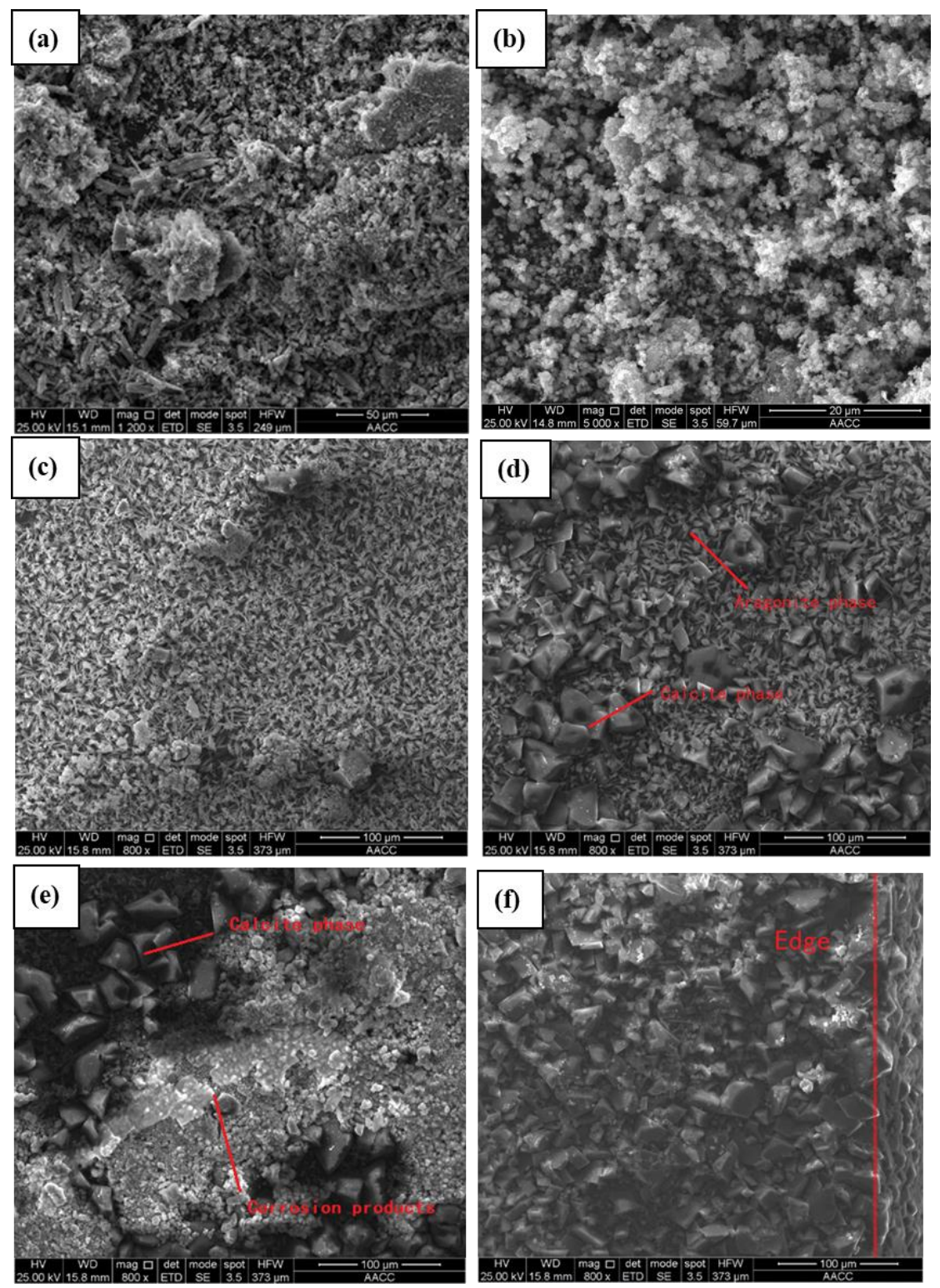

Figure 7. Surface morphology of the specimen after being fouled $(\mathbf{a}, \mathbf{b})$ uncoated specimen $(\mathbf{c}-\mathbf{f})$ specimen 1.

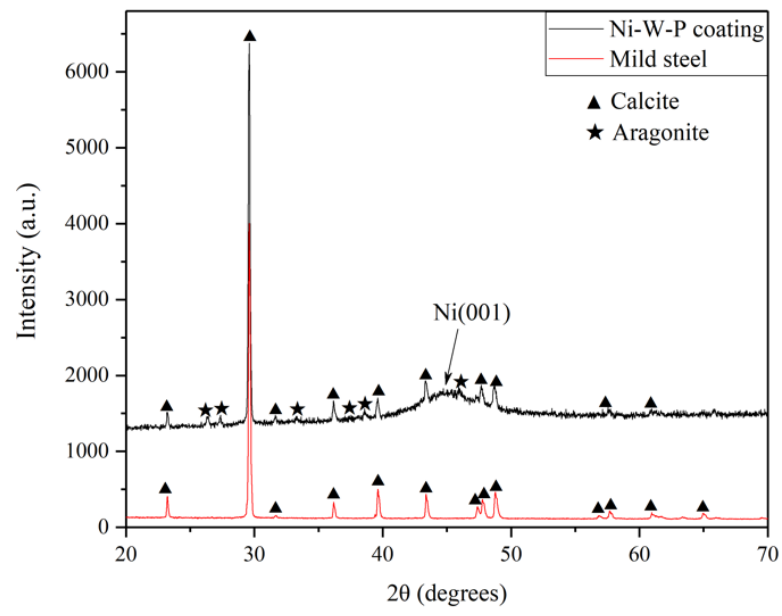

Figure 8. X-ray diffraction pattern of the fouling on specimen surfaces. 


\subsection{Heat Transfer Behavior}

Figure 9a shows the test data obtained from the flow fouling experiment. Water heating tank is used for the heating of flowing water. $\mathrm{CaCO}_{3}$ solution is heated after until temperature range of fouling deposition is $328 \pm 1 \mathrm{~K}$ through the heat transfer of the wall of the inner tube in the measurable anti-fouling heat exchanger temperature. Logarithmic mean temperature difference (LMTD) of measurable anti-fouling heat exchanger is calculated according to the Equation [2].

$$
\Delta t_{m}=\left(\Delta t_{\max }-\Delta t_{\min }\right) / \ln \left(\Delta t_{\max } / \Delta t_{\min }\right)
$$

where $\Delta t_{\max }$ and $\Delta t_{\min }$ represent the maximum and minimum temperature difference of the inlet and outlet in the process of re-fluent heat transfer, K. Equation (14) is then used for determining the heat load of $\mathrm{CaCO}_{3}$ solution and heated water.

$$
\Phi_{4}=q_{m 1} c_{1}\left(t_{1}^{\prime}-t_{1}^{\prime \prime}\right)=q_{m 2} c_{2}\left(t_{2}^{\prime}-t_{2}^{\prime \prime}\right)
$$

where $q_{m 1}$ and $q_{m 2}$ are mass flow rate of water and $\mathrm{CaCO}_{3}$ solution, respectively, $\mathrm{kg} / \mathrm{h} . c_{1}$ and $c_{2}$ are specific heat capacity of water and $\mathrm{CaCO}_{3}$ solution, respectively, $\mathrm{J} /(\mathrm{kg} \cdot \mathrm{K}) . t_{1}^{\prime}$ and $t_{1}^{\prime \prime}$ are the hot side and cool side temperature of water, respectively, K. $t_{2}^{\prime}$ and $t_{2}^{\prime \prime}$ are the hot side and cool side temperature of water, respectively, K.
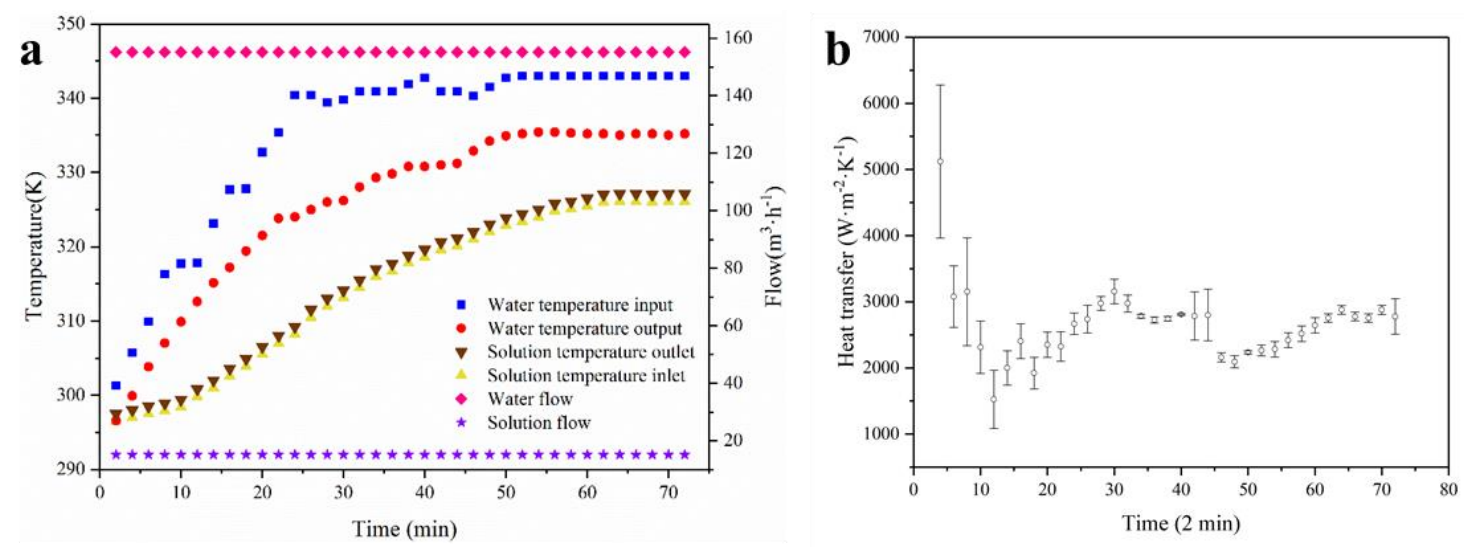

Figure 9. (a) Test data of experimental rig; (b) Heat transfer of measurable anti-fouling heat exchanger.

After that, the heat transfers coefficient of the measurable anti-fouling heat exchanger can be calculated by

$$
k=\Phi_{4} / A^{\prime} \Delta t_{m}
$$

where $A^{\prime}$ is the heat transfer area of inner tube of measurable anti-fouling heat exchanger, $\mathrm{m}^{2}$.

Figure $9 \mathrm{~b}$ displays the heat transfers coefficient change of the measurable anti-fouling heat exchanger. It can be known that the heat transfer coefficient of the designed heat exchanger is stable at about $2500 \mathrm{~W} / \mathrm{m}^{2} \cdot \mathrm{K}$ after $1 \mathrm{~h}$.

The worst problem caused by fouling and oxide deposition is the terrible effect on the heat transfer performance of the material surface. In Figure 7, the uncoated specimen has obvious fouling deposition. Besides, thermal resistance of the Ni-W-P coating itself has contributed to the decrease of the overall heat transfer coefficient of the coated material. Therefore, we specially compare and analyze the heat transfer coefficients of different specimens after fouling at the same time. Meanwhile, the thermal conductivity of ternary Ni-W-P coating was measured to determine the process of thermal conductivity changing with $\mathrm{W}$ content, which is utilized to ascertain the optimum coating parameters.

Figure 10a shows the heat transfer coefficient curves of ternary Ni-W-P coatings with different $\mathrm{W}$ contents. Notwithstanding the $\mathrm{W}$ content has changed, there is un-conspicuous law of corresponding 
heat transfer coefficient. Whereas, the decreasing rate of heat transfer efficiency of the specimen coated with ternary Ni-W-P coating has decreased significantly after $72 \mathrm{~h}$, which proves that the heat transfer performance is better than that of the uncoated mild steel. Although there is still some fouling deposited on the surface of ternary Ni-W-P coating, the thickness of ternary Ni-W-P coating is merely $20 \mu \mathrm{m}$. Compared with the influence of fouling layer, the effect of the coating thickness on the heat transfer of coating can be ignored. As shown in Figure 10a, we can easily know that the heat transfer efficiency of specimen 5 increases with the up of the temperature of the heating source. The up of temperature can improve the heat transfer efficiency of coating while it can also accelerate the deposition rate of $\mathrm{CaCO}_{3}$ fouling, resulting in the further increase of fouling layer thickness. However, the temperature of the heat source should not be reduced unilaterally just in terms of deposition of $\mathrm{CaCO}_{3}$ fouling. How to effectively balance the needs of the economy and efficiency should be in conformity with the actual heat transfer conditions of industrial requirements.
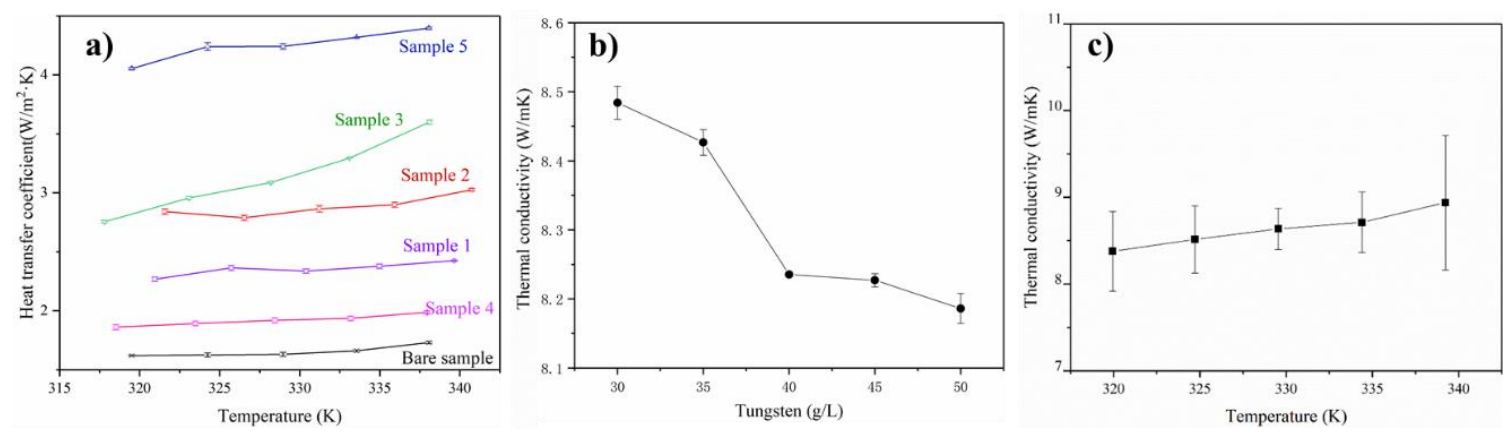

Figure 10. (a) Heat transfer coefficient of specimens after being fouled; (b) Thermal conductively of specimens varied with the temperature; (c) Thermal conductively of specimens varied with tungsten content.

To avoid the measurement deviation of heat transfer coefficient caused by uneven local fouling deposition, we multi-measured the heat transfer coefficient of the specimen coated with ternary Ni-W-P coating before flow fouling experiment. As shown in Figure 10b, it is noticeable that the thermal conductivity of the specimen coated with ternary Ni-W-P coating decreases from $8.48 \mathrm{~W} / \mathrm{m} \cdot \mathrm{K}$ to $8.19 \mathrm{~W} / \mathrm{m} \cdot \mathrm{K}$ with the up of W content. Specifically, excessive $\mathrm{W}$ element deposited on the surface of the substrate with the concentration of sodium tungstate in the plating solution increases, leading to more $\mathrm{W}$ element solid dissolved in amorphous Ni unit cell. The phonon vibration was suppressed and the average kinetic energy of heat transport of electrons as hot carriers decreased during thermal conduction simultaneously $[32,45,46]$. The heat transfer process of the coated specimen thus is inhibited as well. In Figure 10c, the thermal conductivity of the coating increases from $8.38 \mathrm{~W} / \mathrm{m} \cdot \mathrm{K}$ to 8.93 $\mathrm{W} / \mathrm{m} \cdot \mathrm{K}$ with the up of the heat source temperature, which is also consistent with the heat transport mechanism [31,32]. With the increase of temperature, the average velocity of thermal carriers in amorphous $\mathrm{Ni}[\mathrm{W}, \mathrm{P}]$ solid solution increases accordingly. Since the collision process of energy exchange between thermal carriers is more intense and frequent, the heat transfer rate is accelerated and the thermal conductivity of the coating mounts. During this process, the thermal resistance of the un-fouled specimen with ternary Ni-W-P coating decreases from $191,500 \mathrm{Km}^{2} / \mathrm{W}$ to $179,800 \mathrm{Km}^{2} / \mathrm{W}$. This is compatible with the conclusion we analyzed before in Figure 10a.

\subsection{Transient States of Calcite, Aragonite, and Vaterite}

In order to explore the nucleation selectivity of $\mathrm{CaCO}_{3}$ fouling on the different surface of specimens, three different-crystal forms of $\mathrm{CaCO}_{3}$ (calcite, aragonite, and vaterite) were investigated. As shown in Figure 11a, the plane triangle of $\left[\mathrm{CO}_{3}\right]$ is perpendicular to the threefold axis and arranged as layer-structure. The direction of $\left[\mathrm{CO}_{3}\right]$ triangle in the identical layer is the same while the direction of them in the adjacent layer is the opposite. $\mathrm{Ca}$, distributed alternately with $\left[\mathrm{CO}_{3}\right]$, perpendicular to 
the threefold axis is also arranged as layer-structure and in the form of cubic closest packing (CCP). Its coordination number is 6 and the $\mathrm{Ca}$ constitute $\left[\mathrm{CaO}_{6}\right]$ octahedral with $8\left[\mathrm{CO}_{3}\right]$. The structure of aragonite is isomorphic with calcite. $\mathrm{Ca}$ in aragonite is organized in the structure of hexagonal closest packing ( $\mathrm{HCP})$ (Figure $11 \mathrm{~b})$. Ca, as well as $\left[\mathrm{CO}_{3}\right]$ triangles, are well arranged in layer-structure parallel to the aragonite (001). Both of them are arranged alternately along the $\mathrm{c}$ axis and $\left[\mathrm{CO}_{3}\right]$ layers [47]. There are six $\left[\mathrm{CO}_{3}\right]$ around each $\mathrm{Ca}$ and 9 angular top oxides of them are connected to the $\mathrm{Ca}$, forming the nine-fold coordination. In Figure $11 \mathrm{c}$, a hexagonal lattice $\left[\mathrm{CO}_{3}\right]$ groups formed by $\mathrm{Ca}$ is distributed along the hexagonal axis. The number of coordination per cell is at least 12 [48].

Figure $11 \mathrm{~d} 1$ shows the PDOS of calcite. It can be viewed that the peaks of $3 p$ orbit of calcite are at $-19,-18,-8 \mathrm{eV}$ and the peaks of $4 \mathrm{~s}$ orbit is at $-38 \mathrm{eV}$. On the bonding of $\mathrm{Ca}-\left[\mathrm{CO}_{3}\right], 3 \mathrm{p}$ orbit of $\mathrm{Ca}$ and the $2 \mathrm{~s}$ orbit of $\mathrm{O}$ have obvious resonance at $-18 \mathrm{eV}$. Additionally, resonances are established by the $2 \mathrm{p}$ orbit of $\mathrm{C}$ and the $3 \mathrm{p}$ orbit of $\mathrm{Ca}$ at $-18 \mathrm{eV}$, indicating that they are likewise bonded. Comparing with the PDOS in Figure 11d1,d2, we can find that the orbit peaks of the two phases are virtually similar, which manifest that the bond strength and type of them are near-identical [49]. In Figure 11d2, the resonance peaks of the $2 \mathrm{~s}$ orbit of $\mathrm{O}$ and the $3 \mathrm{p}$ orbit of $\mathrm{Ca}$ at $-18 \mathrm{eV}$ are sharper than that of the calcite. This is because the difference of the coordination number of $\mathrm{Ca}$ with $\left[\mathrm{CO}_{3}\right]$ in the two different-crystal structures. Their coordination number is 6 and 9, respectively. From the PDOS of vaterite in Figure 11d3, it is clearly observed that the resonance region shifts to the negative direction obviously and $2 \mathrm{~s}$ orbit of $\mathrm{C}$ resonates with the $4 \mathrm{~s}$ orbit of $\mathrm{Ca}$ at $-42 \mathrm{eV}$. Meantime, $2 \mathrm{p}$ orbit of $\mathrm{C}$ contributes to $3 p$ orbit of $\mathrm{Ca}$ at -24 and $-22 \mathrm{eV}$, which proves that $\mathrm{Ca}$ have a stronger effect on $\mathrm{C}$ in the vaterite phase structure and leads to multi-orbit bonding of $\mathrm{Ca}-\left[\mathrm{CO}_{3}\right]$. Antibonding orbits in vaterite move to the negative direction as a whole compared with calcite and aragonite, showing that the bonding effect in vaterite decreases.

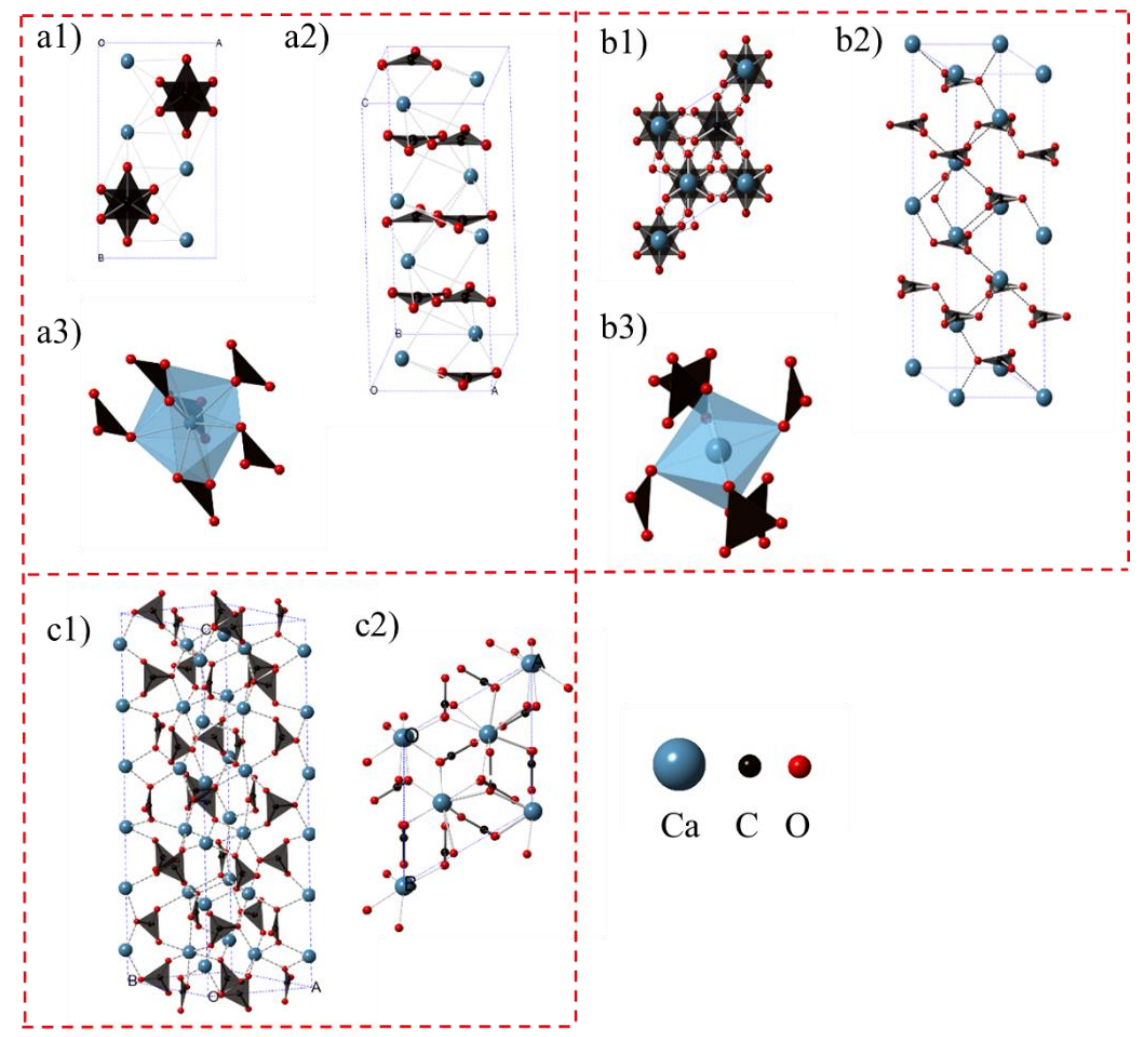

Figure 11. Cont. 


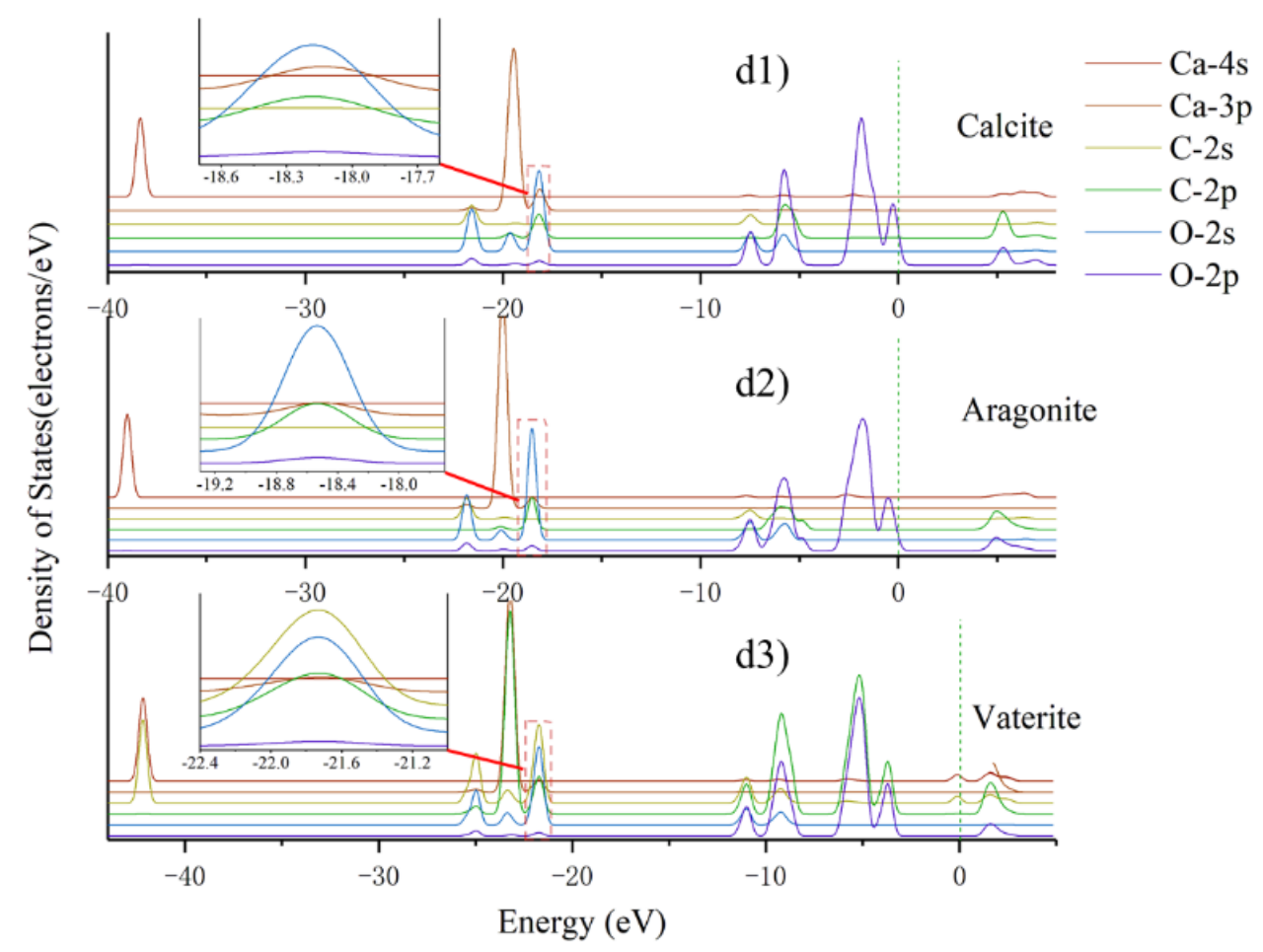

Figure 11. Structure of three crystal calcium carbonate (a1-3) calcite; (b1-3) aragonite; (c1-2) vaterite; (d1-3) density of state of calcite, aragonite, and vaterite.

The geometry optimization in $\mathrm{Dmol}^{3}$ module was used to minimize the energy of super-cell. Meantime, electronic exchange was disposed with the Perdew-Burke-Ernzerhof (PBE) [35,36] function of Generalized Gradient Approximation (GGA) when minimizing the energy. The total energy of different-crystal nucleation of $\mathrm{Ca}^{2+}$ and $\left[\mathrm{CO}_{3}\right]^{2-}$ was computed in Table 5. As shown in Figure 12b, it displays an energetic profile for potential energy surface of calcite, vaterite, and aragonite by relative energy $E$. The energy of nucleation of calcite, aragonite, and vaterite formed by the $\mathrm{Ca}^{2+}$ and $\left[\mathrm{CO}_{3}\right]^{2-}$ decreases. The corresponding decreased energy of a single molecule are $2.13 \mathrm{eV}, 2.68 \mathrm{eV}$, and $2.43 \mathrm{eV}$, respectively. The energy barriers of the transition state TSla, TS1b, and TS1c between free-state ions and their crystal phase are $0.66,0.18$, and $0.10 \mathrm{eV}$, respectively. During the banding process, the distance between $\mathrm{Ca}^{2+}$ and $\left[\mathrm{CO}_{3}\right]^{2-}$ reduces. In addition, it is found that $\mathrm{Ca}^{2+}$ attacked $\left[\mathrm{CO}_{3}\right]^{2-}$ and formed the multi-intermediate under different attacking sites when computing the TS1a. Similarly, the calculations of the transition state for the intermediate of vaterite and aragonite show multi-intermediates. The frequency analysis and calculation of the reaction intermediates, as well as transition states were conducted to optimize structures. After the consequence shows only one imaginary frequency, the only one structure in the transition state of TSla, TSlb, TSlc, TS2, TS3, and TS4 were ascertained authentically and accurately. Meanwhile, during the process of crystal transition of calcite, aragonite, and vaterite, the crystal type of $\mathrm{CaCO}_{3}$ will also change due to different pressure and temperature [50-54]. According to Figure 12b, it is a need to cross the corresponding energy barrier in the process of mutual transformation under the experimental conditions $(328.15 \mathrm{~K}, 0.1 \mathrm{MPa})$. Additionally, the relative stretch length of the intermediate of $\mathrm{Ca}^{2+}$ and $\left[\mathrm{CO}_{3}\right]^{2-}$ is $0.220 \AA, 0.027 \AA$, and $0.095 \AA$, respectively. In the previous research, the ternary Ni-W-P coating has the lower surface free energy based on the experimental results of contact angle Figure 12a $[9,10,16]$. With the decrease of $\mathrm{W}$ content, the surface free energy of Ni-W-P coating was also lower. Take the consequence of Figure $12 \mathrm{~b}$ into consideration, as the free $\mathrm{Ca}^{2+}$ and $\left[\mathrm{CO}_{3}\right]^{2-}$ are easy to transfer to the transition state TS1c with low energy barrier on the surface of Ni-W-P coatings with low surface energy, $\mathrm{CaCO}_{3}$ is prone to nucleate into structure of aragonite-phase $[55,56]$. Besides, because of the influence of high surface free energy on the surface of bare substrate and Ni-W-P coating with high $\mathrm{W}$ content, $\mathrm{Ca}^{2+}$ and $\left[\mathrm{CO}_{3}\right]^{2-}$ in free state can cross high energy barrier and form calcite-phase $\mathrm{CaCO}_{3}$ 
fouling [43], which is consistent with our previous mesoscopic results of the fouling crystal types on the surface of Ni-W-P coating. Refer to Figure 11, we can know that the crystal configuration of both calcite-phase and aragonite-phase is more stable than that of vaterite. In this case, vaterite belongs to the structure of unsteady state [43]. Thereupon, the vaterite transformed to calcite and aragonite can be regarded as the process of transforming the stable phase or the metastable phase to the unsteady state [48] and vaterite undoubted is the dissipative structure. The thermodynamic performance of vaterite is unstable [49], and it will be transformed into a more stable structure of aragonite or calcite phase in the subsequent reaction.

Table 5. Energy and frequency of reaction of $\mathrm{Ca}^{2+}$ and $\left[\mathrm{CO}_{3}\right]^{2-}$.

\begin{tabular}{ccc}
\hline Species & Energy $\mathbf{( e V )}$ & Vibrational Frequency $\left(\mathbf{c m}^{-\mathbf{1}}\right)$ \\
\hline Ion state & -22.05315 & - \\
Calcite & -23.79033 & - \\
Vaterite & -24.09105 & - \\
Aragonite & -24.34573 & - \\
TS1a & -21.38945 & 1425.5 \\
TS1b & -21.86688 & 1405.0 \\
TS1c & -21.94878 & 1412.9 \\
TS2 & -23.69758 & 1411.9 \\
TS3 & -23.71231 & 1487.0 \\
TS4 & -23.77383 & 1474.2 \\
\hline
\end{tabular}
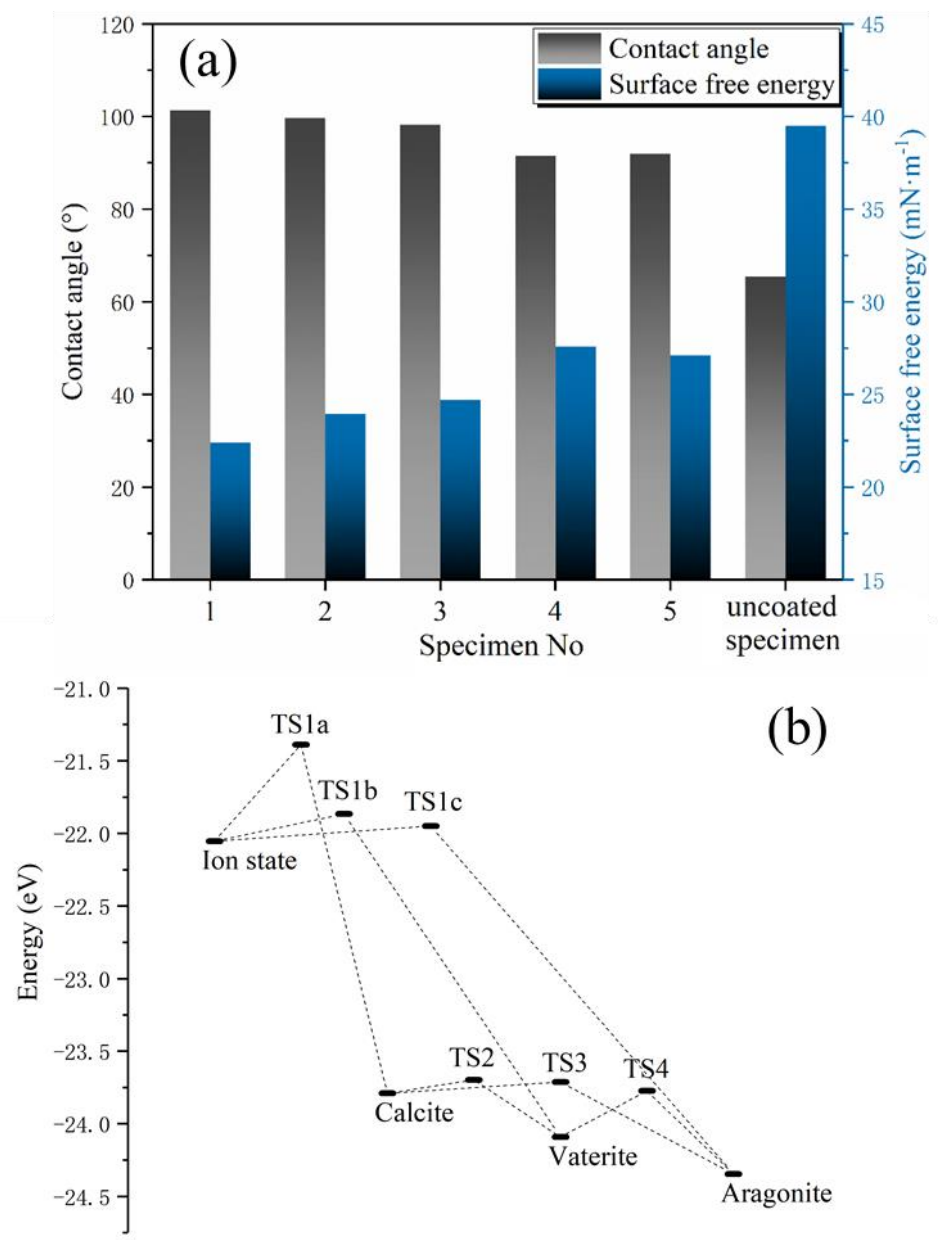

Figure 12. (a) Contact angle and surface energy of uncoated specimen and the Ni-W-P coatings; (b) Energetic profile for potential energy surface of calcite, vaterite, and aragonite. 


\section{Discussion}

Via the aforementioned studies, we evidenced that the deposition of $\mathrm{CaCO}_{3}$ fouling can be effectively inhibited by ternary Ni-W-P coating after fouling in a certain period of time. This can reduce the decreasing rate of the heat transfer efficiency of the substrate surface caused by fouling. Because of the different energy barriers of transition state during the nucleation process of different lattice types of $\mathrm{CaCO}_{3}$ fouling, the nucleation process on surface with different free energy was induced distinguishingly [54,55], resulting in different types of calcite-phase, aragonite-phase, and vaterite-phase $\mathrm{CaCO}_{3}$ fouling deposited on surfaces. Moreover, the changes in the thermal conductivity of ternary Ni-W-P coating were principally caused by the difference of the hot carriers of the different phase structure in the energy transfer process.

Although ternary Ni-W-P coating can obviously inhibit the deposition process of $\mathrm{CaCO}_{3}$ fouling and oxide, it should also be conditional in its application because of the thermal resistance of ternary $\mathrm{Ni}-\mathrm{W}-\mathrm{P}$ coating itself. Fortunately, we found that after $72 \mathrm{~h}$ of depositing in high concentration supersaturated fouling solution, the thermal resistance of the coating has been offset by the influence of a thicker fouling layer. Nevertheless, the Ni-W-P coating with low W content should be used as the anti-fouling interface firstly in the field of industrial heat. One reason is that it can ensure a good heat transfer efficiency. The other reason is that it can more effectively inhibit the excessive deposition of hard-to-remove calcite-phase $\mathrm{CaCO}_{3}$ fouling on the surface.

\section{Conclusions}

In this work, specimens with Ni-W-P coating were prepared for the purpose of flow anti-fouling. Consequently, the oxidation products are always accompanied by deposits of calcite-phase $\mathrm{CaCO}_{3}$ fouling. Due to the low surface energy of ternary Ni-W-P coating, $\mathrm{Ca}^{2+}$ and $\left[\mathrm{CO}_{3}\right]^{2-}$ are prone to cross the transition state with a low energy barrier, resulting in the more formation of aragonite-phase $\mathrm{CaCO}_{3}$ fouling on ternary Ni-W-P coating. Nevertheless, because of the interaction of high surface energy and oxidation products on the bare substrate or Ni-W-P coating with superior $\mathrm{W}$ content, free $\mathrm{Ca}^{2+}$ and $\left[\mathrm{CO}_{3}\right]^{2-}$ can climb over TS1a of high energy barrier and eventually nucleate into calcite. The thermal conductivity of ternary Ni-W-P coating decreases with the increase of W content. Additionally, it goes up with the increase of heat source temperature. As time goes on, the heat transfer efficiency of coated surface after fouling is superior to the bare substrate with fouling layer.

Author Contributions: Resources, writing—original draft preparation, L.R.; writing—review and editing, funding acquisition, Y.C.; resources, J.Y.; writing-review and editing, Q.W.; All authors have read and agreed to the published version of the manuscript.

Funding: This work was supported by the National Natural Science Foundation of China (NO. 51676205), the Key R\&D Plan of Jiangsu Province (BE2019032) and a Project Funded by the Priority Academic Program Development of Jiangsu Higher Education Institutions.

Conflicts of Interest: The authors declare no conflicts of interest.

\section{Abbreviations}

$\begin{array}{ll}\text { DFT } & \text { Density Functional Theory } \\ \text { SEM } & \text { Scanning Electron Microscope } \\ \text { EDS } & \text { Energy Dispersive Spectroscopy } \\ \text { LMTD } & \text { Logarithmic Mean Temperature Difference } \\ \text { CCP } & \text { Cubic Closest Packing } \\ \text { HCP } & \text { Hexagonal Closest Packing } \\ \text { GGA } & \text { Generalized Gradient Approximation } \\ \text { PBE } & \text { Perdew-Burke-Ernzerhof Function } \\ \text { LST } & \text { Linear Synchronous Transit }\end{array}$




\section{References}

1. Kuruneru, S.T.W.; Sauret, E.; Saha, S.; Gu, Y. Numerical investigation of the temporal evolution of particulate fouling in metal foams for air-cooled heat exchangers. Appl. Energy 2016, 184, 531-547. [CrossRef]

2. Maddahi, M.; Hatamipour, M.S.; Jamialahmadi, M. Experimental study of calcium sulfate fouling in a heat exchanger during liquid-solid fluidized bed with cylindrical particles. Int. J. Therm. Sci. 2018, 125, 11-22. [CrossRef]

3. Diaz-Bejarano, E.; Behranvand, E.; Coletti, F.; Mozdianfard, M.R.; Macchietto, S. Organic and inorganic fouling in heat exchangers-Industrial case study: Analysis of fouling state. Appl. Energy 2017, 206, 1250-1266. [CrossRef]

4. Hu, T.; Chen, W.; Yan, N.; Liang, N.; Liu, J. On the morphology and crystallography of the strengthening precipitates in an aged Cu-Ni-P alloy. J. Alloys Compd. 2017, 729, 84-88. [CrossRef]

5. Ren, L.; Cheng, Y.-H.; Wang, S.; Meng, X.; Qin, Q.; Yang, J. Oxidation behavior of the supercritical water on the ternary Ni-W-P coating. Chem. Eng. J. 2019, 370, 1388-1406. [CrossRef]

6. Zielinska, K.; Stankiewicz, A.; Szczygieł, I. Electroless deposition of Ni-P-nano-ZrO2 composite coatings in the presence of various types of surfactants. J. Colloid Interface Sci. 2012, 377, 362-367. [CrossRef]

7. Yanhai, C.; Ren, L.; Xianliang, M.; Jinyong, Y.; Xianhua, T.; Cheng, Y.; Ren, L.; Meng, X.; Yang, J.; Tian, X. The effect of PTFE addition on mechanical and anti-corrosion properties of coating of heat exchangers. Mater. Res. Express 2019, 6, 085207. [CrossRef]

8. Ren, L.; Cheng, Y.; Han, Z.; Meng, X.; Yang, J. Investigation on the mechanical performance of the electroless Ni-W-P coating based on fractal theory. Surf. Topogr. Metrol. Prop. 2019, 7, 025017. [CrossRef]

9. Cheng, Y.H.; Chen, S.S.; Jen, T.C.; Zhu, Z.C.; Peng, Y.X. Effect of copper addition on the properties of electroless Ni-Cu-P coating on heat transfer surface. Int. J. Adv. Manuf. Technol. 2014, 76, 2209-2215. [CrossRef]

10. Cheng, Y.; Cao, S.; Hou, Q.; Han, D.; Han, Z. Effect of Tungsten Addition on the Anti-fouling Property of the Electroless Ni-W-P Deposits. Rare Metal Mater. Eng. 2016, 45, 1931-1937.

11. Cheng, Y.; Chen, H.; Zhu, Z.; Jen, T.; Peng, Y. Experimental study on the anti-fouling effects of Ni-Cu-P-PTFE deposit surface of heat exchangers. Appl. Therm. Eng. 2014, 68, 20-25. [CrossRef]

12. Hu, J.; Wang, B.; Xu, Y.; Zhou, L. The Anticorrosive and Antifouling Properties of Ni-W-P-nSiO2 Composite Coating in A Simulated Oilfield Environment. JOM 2018, 70, 2619-2625. [CrossRef]

13. Ren, L.; Cheng, Y.; Feng, S.; Han, Z. Experimental study on corrosion-fouling relationship of Ni-W-P composite coating surface of heat exchanger. Surf. Topogr. Metrol. Prop. 2019, 7, 015011. [CrossRef]

14. Zhang, W.; Yang, Z.; Kaufman, Y.; Bernstein, R. Surface and anti-fouling properties of a polyampholyte hydrogel grafted onto a polyethersulfone membrane. J. Colloid Interface Sci. 2018, 517, 155-165. [CrossRef] [PubMed]

15. Zettler, H.U. Effect of Surface Properties and Flow Distribution on Fouling of Heat Transfer Surfaces; Doctor of Philosophy in Engineering Type, University of Surrey: Guildford, UK, 2002.

16. Cheng, Y.; Zou, Y.; Cheng, L.; Liu, W. Effect of the microstructure on the anti-fouling property of the electroless Ni-P coating. Mater. Lett. 2008, 62, 4283-4285. [CrossRef]

17. Ren, L.; Cheng, Y.-H.; Wang, Q.; Yang, J. Simulation of the relationship between calcium carbonate fouling and corrosion of iron surface. Colloids Surf. A Physicochem. Eng. Asp. 2019, 582, 123882. [CrossRef]

18. Cheng, L.; Cheng, Y.; Xin, G.; Zou, Y. Influence of Ni-P Coating Microstructure on Condensation Heat Transfer. In Proceedings of the 2010 14th International Heat Transfer Conference, Washington, DC, USA, 8-13 August 2010; Volume 1, pp. 107-113.

19. Lara, J.R.; Holtzapple, M.T. Experimental investigation of dropwise condensation on hydrophobic heat exchangers. Part II: Effect of coatings and surface geometry. Desalination 2011, 280, 363-369. [CrossRef]

20. Westin, K.-J.; Rasmuson, Å.C. Crystal growth of aragonite and calcite in presence of citric acid, DTPA, EDTA and pyromellitic acid. J. Colloid Interface Sci. 2005, 282, 359-369. [CrossRef]

21. Hasson, D.; Semiat, R.; Shemer, H. A kinetic approach to desalinated water corrosion control by $\mathrm{CaCO}_{3}$ films. Desalination 2019, 449, 50-54. [CrossRef]

22. Sancho-Tomás, M.; Fermani, S.; Reggi, M.; García-Ruiz, J.M.; Morales, J.G.; Falini, G. Polypeptide Effect on $\mathrm{Mg} 2+\mathrm{Hydration}$ Inferred from $\mathrm{CaCO}_{3}$ Formation: A Biomineralization Study by Counter-Diffusion. CrystEngComm 2016, 18, 3265-3272. [CrossRef] 
23. Kadota, K.; Furukawa, R.; Shirakawa, Y.; Shimosaka, A.; Hidaka, J. Effect of surface properties of calcium carbonate on aggregation process investigated by molecular dynamics simulation. J. Mater. Sci. 2013, 49, 1724-1733. [CrossRef]

24. Jun, K.A.A.M. Molecular dynamics simulation of the phase transition between calcite and $\mathrm{CaCO}_{3}$-II. J. Phys . Condens. Mater. 2009, 21, 275403.

25. Jun, K.A.A.M. Molecular dynamics simulation of the rotational order-disorder phase transition in calcite. J. Phys. Condens. Mater. 2009, 21, 95406.

26. Kadota, K.; Furukawa, R.; Tozuka, Y.; Shimosaka, A.; Shirakawa, Y.; Hidaka, J. Formation mechanism of non-spherical calcium carbonate particles in the solution using cluster-moving Monte Carlo simulation. J. Mol. Liq. 2014, 194, 115-120. [CrossRef]

27. Ren, L.; Cheng, Y.-H.; Wang, Q.; Tian, X.; Yang, J.; Zhang, D. Relationship between corrosion product and fouling growth on mild steel, copper and brass surface. Colloids Surf. A Physicochem. Eng. Asp. 2020, 591, 124502. [CrossRef]

28. Bogacz, W.; Lemanowicz, M.; Al-Rashed, M.H.; Nakonieczny, D.; Piotrowski, T.; Wójcik, J. Impact of roughness, wettability and hydrodynamic conditions on the incrustation on stainless steel surfaces. Appl. Therm. Eng. 2017, 112, 352-361. [CrossRef]

29. Al-Janabi, A.; Malayeri, M.R.; Badran, O. Performance of shot peened surfaces subject to crystallization fouling. Int. J. Therm. Sci. 2017, 111, 379-389. [CrossRef]

30. Goodenough, J.L.; Reuter, H. Performance characteristics of artificial coatings applied to steam surface condensers. Int. J. Therm. Sci. 2014, 85, 123-137. [CrossRef]

31. Goldstein, R.J.; Ibele, W.E.; Patankar, S.V.; Simon, T.W.; Kuehn, T.H.; Strykowski, P.J.; Tamma, K.K.; Heberlein, J.V.R.; Davidson, J.H.; Bischof, J.; et al. Heat transfer-A review of 2005 literature. Int. J. Heat Mass Transf. 2010, 53, 4397-4447. [CrossRef]

32. Phillpot, S.R.; McGaughey, A.J. Introduction to thermal transport. Mater. Today 2005, 8, 18-20. [CrossRef]

33. Politzer, P.; Daiker, K.C. Some potential-energy relationships for isoelectronic atomic series. Int. J. Quantum Chem. 1978, 14, 245-251. [CrossRef]

34. Ohnishi, S.; Freeman, A.J.; Weinert, M. Surface magnetism of Fe(001). Phys. Rev. B 1983, 28, 6741-6748. [CrossRef]

35. Blochl, P.E. Projector Augmented-Wave Method. Phys. Rev. B 1994, 50, 17953-17979. [CrossRef]

36. Vanderbilt, D. Soft self-consistent pseudopotentials in a generalized eigenvalue formalism. Phys. Rev. B 1990, 41, 7892-7895. [CrossRef]

37. Monkhorst, H.J.; Pack, J.D. Special points for Brillouin-zone integrations. Phys. Rev. B 1976, 13, 5188-5192. [CrossRef]

38. Yeo, S.C.; Han, S.S.; Lee, H.M. Mechanistic Investigation of the Catalytic Decomposition of Ammonia (NH3) on an Fe(100) Surface: A DFT Study. J. Phys. Chem. C 2014, 118, 5309-5316. [CrossRef]

39. Ren, L.; Cheng, Y.-H.; Shao, R.; Meng, X.; Yang, J.; Wang, Q. DFT studies of adsorption properties and bond strengths of H2S, HCN and NH3 on Fe(1 0 0). Appl. Surf. Sci. 2020, 500, 144232. [CrossRef]

40. Lister, V.; Davidson, J.F.; Wilson, D.I. Calculating thermal fouling resistances from dynamic heat transfer measurements. Chem. Eng. Sci. 2012, 84, 772-780. [CrossRef]

41. Nan, Z.; Chen, X.; Yang, Q.; Wang, X.; Shi, Z.; Hou, W. Structure transition from aragonite to vaterite and calcite by the assistance of SDBS. J. Colloid Interface Sci. 2008, 325, 331-336. [CrossRef]

42. Ševčík, R.; Sasek, P.; Viani, A. Physical and nanomechanical properties of the synthetic anhydrous crystalline $\mathrm{CaCO}_{3}$ polymorphs: Vaterite, aragonite and calcite. J. Mater. Sci. 2017, 53, 4022-4033. [CrossRef]

43. Lin, S.-J.; Huang, W.-L. Polycrystalline calcite to aragonite transformation kinetics: Experiments in synthetic systems. Contrib. Miner. Pet. 2004, 147, 604-614. [CrossRef]

44. Nguyen, H.-D.T.; Pham, H.-T.; Wang, D.-A. A miniature pneumatic energy generator using Kármán vortex street. J. Wind. Eng. Ind. Aerodyn. 2013, 116, 40-48. [CrossRef]

45. Wang, X.; Shen, S. Effects of temperature and strain on thermal properties of Ni/Al laminated structure. Comput. Mater. Sci. 2014, 84, 13-17. [CrossRef]

46. Yuan, S.P.; Jiang, P.-X. Thermal Conductivity of Small Nickel Particles. Int. J. Thermophys. 2006, 27, 581-595. [CrossRef] 
47. Ryu, M.; Kim, H.; Lim, M.; You, K.; Ahn, J. Comparison of Dissolution and Surface Reactions between Calcite and Aragonite in L-Glutamic and L-Aspartic Acid Solutions. Molecules 2010, 15, 258-269. [CrossRef] [PubMed]

48. Mugnaioli, E.; Andrusenko, I.; Schüler, T.; Loges, N.; Dinnebier, R.E.; Panthöfer, M.; Tremel, W.; Kolb, U. Ab Initio Structure Determination of Vaterite by Automated Electron Diffraction. Angew. Chem. Int. Ed. 2012, 51, 7041-7045. [CrossRef] [PubMed]

49. Liu, C.; Zheng, H.; Wang, D. Raman spectroscopic study of calcite III to aragonite transformation under high pressure and high temperature. High Press. Res. 2017, 37, 545-557. [CrossRef]

50. Sekkal, W.; Taleb, N.; Shahrour, I.; Zaoui, A. A lattice dynamical study of the aragonite and post-aragonite phases of calcium carbonate rock. Am. Miner. 2008, 93, 1608-1612. [CrossRef]

51. Parker, J.E.; Thompson, S.P.; Lennie, A.R.; Potter, J.; Tang, C.C. A study of the aragonite-calcite transformation using Raman spectroscopy, synchrotron powder diffraction and scanning electron microscopy. CrystEngComm 2010, 12, 1590. [CrossRef]

52. Koga, N.; Kasahara, D.; Kimura, T. Aragonite Crystal Growth and Solid-State Aragonite-Calcite Transformation: A Physico-Geometrical Relationship via Thermal Dehydration of Included Water. Cryst. Growth Des. 2013, 13, 2238-2246. [CrossRef]

53. Gomez-Villalba, L.S.; López-Arce, P.; De Buergo, M.A.; Fort, R. Atomic Defects and Their Relationship to Aragonite-Calcite Transformation in Portlandite Nanocrystal Carbonation. Cryst. Growth Des. 2012, 12, 4844-4852. [CrossRef]

54. Huraiová, M.; Milovský, R.; Hurai, V.; Luptáková, J.; Konečný, P. High-pressure aragonite phenocrysts in carbonatite and carbonated syenite xenoliths within an alkali basalt. Am. Miner. 2013, 98, 1074-1077. [CrossRef]

55. Koga, N.; Nishikawa, K. Mutual Relationship between Solid-State Aragonite-Calcite Transformation and Thermal Dehydration of Included Water in Coral Aragonite. Cryst. Growth Des. 2014, 14, 879-887. [CrossRef]

56. Balaz, M.; Bujňáková, Z.; Bala, P.; Zorkovská, A.; Dankova, Z.; Briancin, J. Adsorption of cadmium(II) on waste biomaterial. J. Colloid Interface Sci. 2015, 454, 121-133. [CrossRef]

(C) 2020 by the authors. Licensee MDPI, Basel, Switzerland. This article is an open access article distributed under the terms and conditions of the Creative Commons Attribution (CC BY) license (http://creativecommons.org/licenses/by/4.0/). 